This manuscript is contextually identical with the following published paper:

Heilmann-Clausen, J., Aude, E., van Dort, K., Christensen, M., Piltaver, A., Veerkamp, M., Walleyn ${ }^{\dagger}$, R., Siller, I., Standovár, T., Òdor, P. 2014. Communities of wood-inhabiting bryophytes and fungi on dead beech logs in Europe - reflecting substrate quality or shaped by climate and forest conditions? Journal of Biogeography 41: 2269-2282. DOI:

10.1111/jbi.12388

The original published pdf available in this website:

http://onlinelibrary.wiley.com/doi/10.1111/jbi.12388/abstract

\title{
Communities of wood-inhabiting bryophytes and fungi on dead beech logs in Europe - reflecting substrate quality or shaped by climate and forest conditions?
}

Jacob Heilmann-Clausen ${ }^{1 *}$, Erik Aude ${ }^{2}$, Klaas van Dort ${ }^{3}$, Morten Christensen ${ }^{4}$, Andrej Piltaver $^{5}$, Mirjam Veerkamp ${ }^{6}$, Ruben Walleyn ${ }^{\dagger}$, ${\text { Irén } \text { Siller }^{7} \text {, Tibor Standovár }}^{8}$, Péter Òdor ${ }^{9}$

${ }^{1}$ Center for Macroecology, Evolution and Climate, Biological Institute, University of Copenhagen, Universitetsparken 15, DK-2100 Copenhagen, Denmark, ${ }^{2}$ HabitatVision A/S, Solsortevej 7, DK-8410 Rønde, Denmark, ${ }^{3}$ Forestfun, Leeuweriksweide 186, NL-6708 LN Wageningen, The Netherlands, ${ }^{4}$ Hvidtjørnevej 1, 4180 Sorø, Denmark, ${ }^{5}$ Institute for systematic of higher fungi, Zofke Kvedrove 24, SI-1000 Ljubljana, Slovenia, ${ }^{6}$ Pelikaanweg 54, NL-3985RZ Werkhoven, The Netherlands, ${ }^{7}$ Institute for Biology, Faculty of Veterinary Science, Szent István University, H-1400 Budapest, Pf. 2., Hungary

(Turcsanyine.Siller.Iren@ aotk.szie.hu), ${ }^{8}$ Department of Plant Systematics, Ecology and Theoretical Biology, Eötvös University, Pázmány P. stny. 1/C, H-1117 Budapest, Hungary (standy@ludens.elte.hu), ${ }^{9}$ MTA Centre for Ecological Research, Institute of Ecology and Botany, H-2163 Vácrátót, Alkotmány u. 2-4., Hungary (odor.peter@okologia.mta.hu).

\section{Running title}

Bryophytes and fungi on dead beech logs in Europe

\section{Keywords}

Biodiversity, community gradients, dead wood, decomposers, Fagus sylvatica, forest reserves, guilds, landscape history, variation partitioning, wood-decay 


\section{Abstract}

Aim Fungi are drivers of wood-decay in forested ecosystem, while bryophytes use dead wood as a platform for their autotrophic lifestyle. We tested the hypothesis that fungal communities on beech logs are mainly structured by substrate quality, while bryophyte communities are structured by climatic gradients. In addition we tested if community structure in both organism groups is altered along a gradient from nearly pristine forest to forests heavily affected by management and human disturbance in the past.

\section{Location Europe}

Methods We surveyed 1207 fallen beech logs in 26 of the best preserved forest stands across six European countries, representing a gradient in overall naturalness of the forest landscape. Recorded species were classified in ecological guilds. Indirect ordination and variation partitioning was used to analyse the relation between species composition and environmental variables, recorded at log or site level.

Results In total, 10,367 bryophyte and 15,575 fungal records were made, representing 157 and 272 species, respectively. Fungal communities were most clearly structured by substrate quality compared to bryophyte ones. In both groups a distinct turnover in species composition was evident along a longitudinal gradient from Central to Western Europe. Fungi specialised in trunk rot and specialised epixylic bryophytes were scarcely represented in Atlantic regions, and partly replaced by species belonging to less specialised guilds. Variables related to climate and forest conditions were confounded along this main geographical gradient in community composition

Main conclusions We found bryophyte and fungal communities co-occurring on fallen beech $\operatorname{logs}$ in European beech forest reserves to differ in their response to biogeographical drivers and local scale habitat filters. Both groups responded to major gradients in climate and forest conditions, but the loss of specialist guilds in degraded forest landscapes points to a functionally important effect of forest landscape degradation at the European continental scale. 


\section{INTRODUCTION}

It is well known that diversity patterns may differ among organism groups, along elevational, latitudinal and human disturbance gradients (e.g. Fukami \& Wardle, 2005; Rahbek, 2005; Sundquist et al., 2013), but in many cases it is poorly understood why these differences occur. Comparisons across taxonomical or functional groups are one way to increase understanding of these patterns (Fukami \& Wardle, 2005). In this respect, decaying wood offers an interesting study system, because it hosts several different organism groups playing different functional roles within well-delimited habitat patches. Fungi are the principal drivers of wood-decay (Boddy \& Heilmann-Clausen, 2008) and hence crucial for most other organism groups associated with dead wood. In contrast, wood-living bryophytes are not directly involved in wood decay, but use dead wood as a platform for their autotrophic lifestyle. Some bryophytes are obligate epixylic, but a major part of the species utilising dead wood are able to grow and may even be more common on other substrates, including soil, rocks and the bark of living trees (Stokland et al., 2012).

Beech species (Fagus spp.) are widespread and typical trees of temperate deciduous forests throughout the Northern Hemisphere (Fang \& Lechowicz, 2006; Bradshaw et al., 2010). European beech (Fagus sylvatica L.) is the most widespread species in the genus. It is an important and often dominant tree species throughout temperate lowland forests of Northwest-Europe and in low mountain ranges in Central Europe, following the Appenines down to southern Italy (Bradshaw et al., 2010). European beech forests are among the most degraded and fragmented ecosystems in the world, with less than $0.1 \%$ remaining in near pristine condition (Schmitt et al., 2009; Brunet et al., 2010). Many associated organisms are hence threatened with extinction, nationally or even at the global scale. This is especially the case for specialists associated with habitats - e.g. old trees and decaying wood - lacking in managed forests (Brunet et al., 2010; ). The biogeography of the flora of European beech forests is relatively well known (e.g. Willner et al., 2009) and several recent papers have provided a first European scale assessment of saproxylic beetle diversity (Lachat et al., 2012; Gossner et al. 2013; Müller et al., 2013). In comparison little is known on large scale biodiversity patterns of fungi and bryophytes (Qian et al., 1999; Ódor et al., 2006; HeilmannClausen \& Boddy, 2008).

More broadly, the importance of local habitat filters for determining community structure has been studied quite extensively for both wood-inhabiting fungi and bryophytes, in different forest types. Wood decay stage, tree species and microclimatic factors have been shown to be 
important filters influencing species composition at individual fallen trees in both groups (Ódor \& van Hees, 2004; Heilmann-Clausen et al. 2004; Boddy \& Heilmann-Clausen, 2008). Several studies have found a clear link between lowered dead wood amounts and decreasing species richness in managed forests (for reviews see ; Müller \& Bütler 2010; Laussauce et al., 2011), while others have indicated that forest fragmentation and temporal habitat discontinuity influence species composition at the landscape scale, even in the presence of ample and adequate habitats in local hot spots (e.g. Heilmann-Clausen \& Christensen, 2005; Löbel et al., 2006; Ódor et al., 2006; Paltto et al., 2006). Unfortunately none of these studies accounted for the potential importance of climate in a comprehensive way, and hence it is difficult to evaluate to what degree forest conditions, habitat quality and climate interacts in shaping bryophyte and fungal communities.

In this study we explored community composition of wood-inhabiting bryophytes and fungi based on a comprehensive dataset collected in a standardised way in beech forest reserves across six countries in Europe, from Sweden in the north, Belgium in the west to Slovenia in the south and Hungary in the east. The dataset represents an extension of the dataset analysed by Ódor et al. (2006) that focussed on species richness patterns. For both organism groups the analysed dataset is the geographically most extensive so far using a standardised sampling protocol.

It was our overall expectation that substrate quality, climate and forest conditions all contribute to explain community composition of fungi and bryophytes on fallen logs across study sites. Because fungi have a direct role in wood decay while bryophytes use dead wood only as a substrate we hypothesised that: (1) the relative contribution of substrate quality was stronger for fungi compared to bryophytes; and (2) regional climatic factors were more important for explaining differences in bryophyte community composition. Finally, (3) we hypothesised that variables related to forest conditions (including history) were equally important in explaining community structure in both organism groups, with ecologically degraded communities prevailing in forest landscapes characterized by lack of naturalness and habitat loss.

\section{MATERIAL AND METHODS}

\section{Study objects}


The study was conducted in 26 beech stands, in 16 forest reserves, in Belgium, Denmark, Hungary, The Netherlands, Slovenia and Sweden. The stands represent some of the most natural beech forests within each country. They are all protected as non-intervention forest reserves, but their historical management is very different. Due to an intensive history of forest management and fragmentation, stands in The Netherlands and Sweden were generally small, which is the reason for the study design in these countries, where several small stands aggregated within larger nature reserves were studied (Table 1; Fig. 1). In Belgium only one forest reserve was included, but divided in a core area and a buffer zone with different management history.

In each stand between five (minimum 25 at reserve level) and 125 fallen beech logs were selected following a stratified random approach, with the aim to secure a balanced representation of six log decay stages (see Ódor \& van Hees, 2004) and three diameter classes (diameter at breast height $20-50 \mathrm{~cm} ; 50-80 \mathrm{~cm} ;>80 \mathrm{~cm}$ ). Due to an unbalanced representation of decay stages and size classes, it was not possible to fulfil this goal in some stands, especially in Belgium and The Netherlands. Several variables were recorded for each log in the field, or at stand or reserve level based on various sources. We divided the recorded variables in three variable sets: (i) Substrate variables included all variables recorded in the field to characterize the individual studied log, i.e. size, decay stage, bark and moss cover and soil contact; (ii) Climate and soil variables were recorded at reserve level, and included a number of key variables describing soil type, elevation and temperature, rainfall, snow cover and continentality based on actual measurements from meteorological stations near the study sites; (iii) Forest condition variables were recorded at stand or reserve level and included naturalness, dominant tree age, reserve size and dead wood volume based on actual measurements or recorded data for each stand, as well as several variables describing the current and past (18-19th century) forest cover in a $5 \mathrm{~km}$ radius around the centre point of each stand. A radius of $5 \mathrm{~km}$ has been found to be relevant in earlier landscape studies of wood-inhabiting fungi (Paltto et al., 2006). We also analysed a $10 \mathrm{~km}$ radius in the early phase of analysis, but as this radius always resulted in slightly poorer fit with relevant response variables, we did not include this scale in the final analyses. Details, names and abbreviations of all variables and their classification as substrate, climate and soil or forest condition variables are shown in Table 2. All variables were standardised by range (i.e. obtaining values ranging from 0 to 1 ) before further analyses.

\section{Fungi and bryophyte surveys}


All included logs were surveyed thrice for fungal fruit bodies and once for wood-inhabiting bryophytes recording all species growing directly on wood or bark. The fungal surveys were conducted at three occasions over the fungal season in order to obtain a robust recording of species producing fruit bodies on the studied logs. Among the macrofungi (fungi with fruit bodies visible to the naked eye) all groups were sampled, except fully resupinate corticoid fungi, non-stromatic pyrenomycetes and inoperculate discomycetes with fruit bodies regularly smaller than $10 \mathrm{~mm}$. At each survey fruit bodies were recorded in the field or collected for identification in the laboratory. For both fungi and bryophytes recordings from the log, including the root plate (if present) and major branches of the crown (diameter $>10 \mathrm{~cm}$, if present) and the snag up to $2 \mathrm{~m}$ (if present) were merged for each log. Surveys were carried out in 2001-2002 except for Sweden where field work was conducted in 2004.

For fungi the taxonomic treatment follows Hansen \& Knudsen (1992-2000), but nomenclature has been updated to match with indexfungorum.org (accessed 18. June 2014). For bryophytes nomenclature follows Hill et al. (2006) for mosses, and Grolle \& Long (2000) for liverworts. Plagiochila porelloides and P. asplenioides as well as Plagiothecium nemorale and $P$. succulentum were not separated. Among the fungi Antrodiella semisupina was treated in a collective sense including A. faginea and A. pallescens, Physisporinus sanguinolentus was not distinguished from $P$. vitreus and Pluteus plautus was treated in a collective sense.

\section{Classification of species}

Compared to earlier reports based on part of the present dataset (e.g. Ódor et al., 2006), we excluded some species groups to secure standardized sampling across study sites. Thus litterinhabiting and ectomycorrhizal fungi, which only occasionally occur on dead wood, were omitted. Similarly, in the bryophyte dataset, species associated to the soil of the uprooted part of the logs were omitted. The remaining taxa were classified in ecological guilds. Bryophytes were classified based on their normal substrate preference as epilithic, epiphytic, epixylic, opportunistic or terricolous according to textbooks (Frahm \& Frey, 1992; Smith, 2004; Schumacker \& Vana, 2005) and field experience of the authors (see Odor et al., 2006). Fungi were classified as early ruderals, combative invaders, cord-formers, late stage specialists, trunk rotters or with unknown/other ecology, based primarily on Boddy \& Heilmann-Clausen (2008), but with input from other sources, especially Heilmann-Clausen (2001), Hansen \& Knudsen (1992-2000), and field experience of the authors. For further details see Appendix S1 and S2 in Supporting Information. 


\section{Data analysis}

The overall structure of the fungi and the bryophyte dataset was explored by Detrended Correspondence Analysis (DCA, Hill \& Gauch, 1980) in PCord vers. 4.25. (McCune \& Mefford, 1999). Down-weighting of rare species was not applied, but species poor logs (less than five species) and infrequent species (less than three records) were omitted from the dataset to increase the robustness of results (cf. Økland, 1999). DCA is an unconstrained ordination technique and hence extracted sample scores in the ordination space are based solely on the species recorded on each log. The relationships between DCA axes and environmental variables were studied by simple mixed-effect models (Zuur et al., 2009) using environmental variables as independent, DCA axes as dependent variables and site as a random factor. Owing to confounded variation among some variables and limited degrees of freedom for stand-level variables, we did not attempt to construct more complex multivariate models. In all models the significance of the relationships were tested by F-statistics, and with p-values Bonferroni-Holm adjusted, due to the multiple comparisons. The regression modelling was done in R 2.15.2 environment (The R Development Core Team, 2012), using the "nlme" package (Pinheiro et al., 2011).

The ecological nature of the gradients extracted in DCA, was analysed further by testing for non-random patterns in the distribution of ecological guilds along each DCA axis using one way ANOVAs, based on the DCA axis scores for each species. Tukey's HSD were used for post-hoc comparisons of means.

The relative importance of the three groups of explanatory variables (substrate, climate and soil and forest condition, Table 2) on species composition in both organism groups were analysed by variation partitioning (Legendre \& Legendre, 1998) using partial Canonical Correspondence Analysis (Leps \& Smilauer, 2003). The pool of explanatory variables in each variable set was selected by forward selection via Monte Carlo simulation under the full model using 499 permutations. During the selection process the automatic selection procedure of Canoco 4.5 was used (ter Braak \& Smilauer, 2002).

\section{RESULTS}

In total we recorded 157 species of bryophytes and 272 species of fungi on the 1207 investigated logs. A large proportion of the recorded species occurred on less than three logs, 
and similarly many logs had less than five species present in either group. After pruning out these species poor logs and low frequent species, the bryophyte dataset was reduced to 9689 records of 114 species on 893 study objects, while the fungal dataset contained 12967 records of 210 species on 965 study objects.

In both datasets three ordination axes were extracted in the DCA. In the fungal dataset the ordination axes 1 to 3 had gradient lengths of 3.98, 3.64 and 3.30 SD units respectively, with eigenvalues of $0.40,0.30$ and 0.19 . The DCA of the bryophyte dataset similarly produced ordination axes with lengths of 3.71, 3.52 and 3.58 SD units and corresponding eigenvalues of $0.53,0.32$ and 0.19 .

\section{Relationships between DCA axes and environmental variables}

All extracted ordination axes were significantly related to environmental variables (Table 3), and in both organism groups a clear geographical clustering was evident in the ordination space defined by axis 1 and 2 (Fig. 2).

For bryophytes, the first axis was best explained by snow cover, temperature range, elevation, naturalness and longitude, implying that this axis separated Atlantic lowland sites in northern Europe from highland sites in central Europe with a continental montane climate, long snow cover and high naturalness. The second axis in the bryophyte ordination was, best explained by decay stage and related substrate variables nested within site (Table 3 ). The third bryophyte ordination axis was significantly related only to substrate variables with decay stage having the highest F-value.

In the fungal ordination axis 1 was best explained by decay stage, while axis 2 expressed a geographical gradient (Fig. 2), best explained by longitude and temperature range (Table 3), implying that the axis represented a gradient in continentality. The third and weakest fungal ordination axis was only related to substrate variables with log size (DBH) having the highest F-value. It is important to note that correlation among some environmental variables was very pronounced (Appendix S3) and hence the relations between closely related environmental variables and ordination axes are not independent.

\section{Optima of guilds}

The distribution of bryophyte and fungal guilds was significantly non-random along the analysed DCA ordination axes (ANOVA, $\mathrm{p}<0.0001$ except for axis 3 in the fungal ordination 
with $\mathrm{p}=0.0058$; F-values were $6.3,6.9$ and 28.7 for axes $1-3$ in the bryophyte ordination, and 25.7, 5.3 and 3.4 for the corresponding fungal axes). Among the bryophytes, epilithic and epixylic species had significantly lower optima along axis 1 compared to terricolous and opportunistic species, while epiphytes and epixylic species were separated along axis 2 (Fig. 3). Along axis 3 epiphytes and epilithic species were significantly separated from epixylic, terricolous and opportunistic species. The axis 1 optima of epilithic and epixylic species were lower than the general distribution of samples in the same ordination space, indicating these guilds to have a disproportional strong influence on the community gradient, due to a high prevalence in Slovenia and Hungary.

In the fungal ordination a significant turnover in guilds was evident along ordination axis 1 . Early ruderals had significantly higher optima than all other groups, but also combative invaders had a high optima indicating prevalence on weakly decayed logs. In contrast, late stage specialists had the lowest optima. Along axis 2 species classified as trunk rotters had significantly higher optima than late stage specialists, cord-formers and species with different or unknown strategies. The distribution of cord-formers was narrow and particularly low, indicating this guild to be very sparsely represented towards the continental end of this gradient. Finally late stage specialists were significantly separated from species with unknown or different ecology along axis 3.

\section{Variation partitioning}

The CCA based variation partitioning of the fungal and bryophyte datasets showed marked differences between the two datasets (Fig. 4): Substrate variables independently explained 8 $\%$ of the explained variance in the bryophyte dataset, versus $23 \%$ in the fungal dataset. Climate and soil and forest condition variables in combination accounted for $77 \%$ of the explained variance in the bryophyte dataset, compared to $63 \%$ in the fungal dataset. The individual contribution of climate and soil variables was similar in both datasets (21\%), while variables describing forest conditions were slightly more important in explaining variation in the fungal dataset (20\% versus $15 \%$ ). Further, the shared contribution of forest condition and climate and soil variables was almost double as high in bryophytes (40\%) compared to fungi (22\%). In total, the selected explanatory variables explained $22.7 \%$ of the total inertia in the bryophyte CCA and $10.3 \%$ of the total inertia in the fungal CCA. As shown by Økland (1999) total inertia is not comparable between datasets, and in our case the difference probably reflect inherent differences in data-structure, especially the larger species pool and higher 
frequency of infrequent species in the fungal dataset compared to the bryophyte dataset (cf. Ódor et al. 2006)).

\section{DISCUSSION}

\section{Local filters}

In this study we found clearly different patterns in community structure of wood-inhabiting fungi and bryophytes on fallen beech logs, distributed in 26 protected beech stands in six European countries. Fungal community composition was strongly structured by local filters, particularly wood decay stage at log level, while bryophyte communities were most strongly shaped by site and landscape level filters relating to climate and forest conditions (especially naturalness).

A distinct turnover in fruiting patterns of fungal species composition during wood decay is well established from previous studies (Stokland et al., 2012), but our study is the first to demonstrate the generality of a strong, common decay gradient shaping fungal communities on decaying beech logs at the European continental scale. The optima of fungal guilds along the gradient show a transition from early ruderals in initial decay stages, over combative invaders and trunk rotters in intermediate decay stages and with cord-formers and late stage specialists having the latest optima. This turnover corresponds roughly to a shift from ruderal to combative species, combined with the effect of substrate modification favouring species specialised in utilising residual compounds from previous decay (Heilmann-Clausen, 2001; Boddy \& Heilmann-Clausen, 2008).

For the bryophytes the effect of decay stage was smaller than for fungi and subordinate to the effect of variables related to climate and forest conditions. This may partly reflect that decay stage was estimated based on the physical decay stage of logs, reflecting the activity of decomposer fungi, while time since tree death would be the most relevant variable to address for bryophytes. However, our analyses show a strong geographical differentiation of bryophyte communities within our dataset, with the clear expression of a successional gradient only after accounting for differences in species pools among sites. Several previous studies have reported a clear successional turnover in bryophyte species composition as wood decays, with epiphytes dominating in early decay stages and epixylic species restricted to strongly decayed logs (e.g. Söderström, 1988; Rambo \& Muir, 1998; Ódor \& van Hees 2004; Kushnevskaya et al., 2007). This corresponds very well with the turnover in guilds found 
along ordination axis 2 and 3 in this study, with the interesting addition, that epilithic species, when present, seem to co-occur with epiphytes, while terricolous species grouped with the epixylics.

\section{Geographical gradients in bryophyte communities}

Variables related to climate and forest conditions were confounded along the principal bryophyte community gradient, and the variation partitioning approach suggested that most of the explained variation is shared between both set of variables. Previous studies have found that obligate epixylic bryophytes are sensitive to lack of naturalness at the local scale, due to discontinuity in the presence of suitable substrates, especially large diameter dead logs in managed forests (Andersson \& Hytteborn, 1991; Rambo and Muir, 1998; Saboljevic et al., 2010), but also due to the lack of stability in forest climate caused by forestry operations, facilitating more robust, weft-forming bryophytes that are less sensitive to desiccation (Clausen, 1964; Ódor \& van Hees, 2004). As shown by Ódor et al. (2006) the average alpha diversity (species richness per log) is very variable within our dataset, being very high in Slovenia, and lowest in Belgium, The Netherlands and Denmark, reflecting the principal gradient in bryophyte species composition found in this study. The optima of bryophyte guilds along the first ordination axis showed that bryophyte assemblages in countries with low alpha diversity were dominated by opportunistic and terricolous species, while obligate epixylic, and to a lesser extent epiphytic species were very scarce. Thus, low alpha diversity was related to a depletion of functional types in the community, and in particular to a poor representation of specialised epixylic species on decayed logs. However, a direct or indirect effect of climatic drivers cannot be ruled out, and the strong relation between the first ordination axis and snow cover and elevation is intriguing. In a study from the Czech Republic, Jansová (2006) found that growth and local extinction dynamics of bryophyte communities on beech logs were more intensive in wintertime than in the summer. This suggest that the length of the snow free period in winter may be an important factor structuring epixylic communities, just as it has been shown for groundliving bryophytes in alpine snow-beds (e.g. Hohenwallner et al., 2011). In our dataset, the winterperiod without snow cover was longest for sites in Belgium and The Netherlands, and hence negatively correlated with stand naturalness. Whether a shorter snow cover may benefit opportunistic species, which often have higher growth rates than true epixylic specialists, remains untested. 


\section{Geographical gradients in fungal communities}

Even though the dominant gradient in fungal communities was related to log decay stage, regional filters also play an important role. Thus, axis 2 in the fungal ordination represents a distinct geographical gradient, strongly related to longitude and temperature range, and with weaker relations to several forest condition variables. Overall, this suggests a distinct turnover in fungal community structure with increasing continentality. Wood-inhabiting fungi are known to differ considerably in their microclimatic tolerances and preferences (Boddy \& Heilmann-Clausen, 2008; Stokland et al., 2012) but only a limited number of studies have explored the importance of macroclimate for community composition in wood-inhabiting fungi, and mainly in relation to distinct elevational gradients (Lindblad, 2001; GómezHernández et al., 2012). In a previous paper (Ódor et al., 2006) we suggested that trunk rotters (heart rot agents in Ódor et al. (2006)), which are normally considered stress-tolerant (Boddy \& Heilmann-Clausen, 2008), could be favoured under continental climates. The current guild based analysis lends support to this hypothesis, but due to the confounding of climate and forest condition variables, direct effects of forest history or naturalness cannot be ruled out.

Studies from Fennoscandia have reported a clear relation between forest fragmentation and lack of naturalness on one side and the depletion of fungal communities for habitat specialists on the other (Paltto et al., 2006; Penttilä et al., 2006; Berglund et al., 2011; Nordén et al., 2013). Unfortunately, these studies have not accounted for the potential effect of climate in a comprehensive way, but in a regional scale study in Germany, Bässler et al. (2010) reported that resource availability was more important than climate for wood-inhabiting fungi on large diameter dead wood. In our dataset, trunk rotters constitute an important group of habitat specialists that only produce fruit bodies on large decaying logs or living trunks with internal rot (Boddy \& Heilmann-Clausen, 2008). Hence, their optima in Slovenia and Hungary, hosting the most natural beech stands, could reflect higher continuity in the presence in coarse dead wood habitats and less fragmented forests in this part of Europe. The significant disassociation of trunk rotters with cord-formers and late stage specialists along DCA axis 2 support this interpretation. The two latter guilds all have traits that make them relatively competitive in managed forests with low input of large diameter dead wood: Cord-formers are typically able to grow on various types of woody material, and are very competitive in invading already colonized resources, e.g. dead branches falling from the canopy to the forest floor (Boddy, 1999; Boddy \& Heilmann-Clausen, 2008). Late state specialists include mainly 
basidiomycetes, not least agarics belonging to the genera Mycena, Pluteus and Psathyrella. Except for the preference for well-decayed wood, little is known on the precise habitat requirements in this guild, but they are rarely restricted to large diameter dead wood and several species occur even on cut stumps, sawdust and other man-made substrates (e.g. Runge, 1975; Babos, 1991). In a parallel analysis of the fungal dataset used here, but with a strict focus on forest naturalness we found that beta-diversity was significantly lower in late stages of decay in less natural forest reserves compared to more natural sites (Halme et al., 2013). This could reflect a depletion of trunk-rotters to the benefit of more ruderal cordformers and late stage agarics, resulting in more uniform fungal communities on strongly decayed logs in degraded forests, but further studies are needed to confirm the validity of this hypothesis.

\section{CONCLUSIONS}

In this study we found that bryophyte and fungal communities co-occurring on fallen beech logs in European beech forest reserves differed considerably in their responses to biogeographical drivers and substrate quality. In accordance with our hypothesis 1, fungal communities were structured by a common and strong successional gradient over the European continental scale, while bryophyte communities on the same logs were more strongly structured by regional filters, with effects of substrate quality nested at regional level. In other words, considerable species pool differences were evident for bryophytes, but not for fungi. Species in both groups often have wide distribution ranges, which would assume low effects of species pools. However, several specialised bryophyte species (mainly epixylics) are predominantly dispersed by large asexual diaspores, and hence dispersal limited at the landscape scale (Löbel \& Rydin 2009), which suggest that communities of wood-inhabiting bryophytes might be more sensitive to habitat fragmentation and breaks in continuity than fungal communities.

The tests of hypothesis 2 (regional climatic factors are more important for bryophytes than for fungi) and hypothesis 3 (forest conditions are equally important in both groups) proved difficult due to the confounding of important climatic and forest condition variables along the identified community gradients. However, our results pointed to a pronounced effect of climatic variables on fungal communities at the European scale, and our data do not support wood-inhabiting fungi to be less affected by regional climate compared to bryophytes, although drivers and mechanisms seem to differ among the two organism groups. 
With some variation a distinct community turnover was observed in both wood-inhabiting bryophytes and fungi, along a longitudinal gradient from Central (Slovenia and Hungary) to Western Europe (Belgium \& the Netherlands), with substrate specialists depending on large fallen logs being scarcely represented in the latter countries. Based on this, but also considering the overall landscape history of Europe (Kaplan et al., 2009), we interpret this depletion to reflect mainly a response to the severe forest loss and broken habitat continuity in Western Europe, but with a probable interaction with climatic factors. It seems plausible that both epixylic bryophytes and fungi causing trunk rot might be more competitive in continental climates: Epixylic bryophytes due to the longer period with snow cover, which may decrease competition from more opportunistic species, and trunk rotting fungi due to the higher level of microclimatic stress, reducing competition from cord-formers and late stage specialists. We hope that future studies addressing geographical gradients in biodiversity connected to dead wood can be optimized to focus more on the independent effects of climate and forest history on biodiversity on dead wood. At least in Europe the confounding relation between climate and anthropocentric forest loss and degradation is deeply embedded in history (Kaplan et al., 2009), which makes the design of relevant studies difficult. Carefully designed studies over the naturalness gradient in the core areas of beech at Balkan and in the Carpathians could probably overcome this problem, but we also encourage studies on other tree species, from other continents or using experimental set-ups to increase the knowledge on the generality of climate and habitat loss effects on wood-inhabiting biodiversity.

\section{ACKNOWLEDGEMENTS}

The study was supported by the EU 5th Framework Programme Nat-Man (QLRT1-CT991349). During the preparation of the manuscript the AVJF foundation supported the first author while P.Ó. was supported by the Hungarian Science Foundation (OTKA 68218, 79158) and the János Bolyai Research Scholarship of the Hungarian Academy of Sciences. Slovenian partners were financed through Ministry of Education (Project No. 404-501), Ministry of Agriculture (Project No. 2552/8), Ministry of Environment and Spatial Planning (Project No. 2523-02-100324). Fieldwork in Belgium was supported by the Forestry Department of the Flemish Government (NKB-2001-KUT-5) and in Sweden by the County Administrative Board of Halland. The authors are grateful for fieldwork assistance provided by Szurdoki, E., Kenderes, K., Turcsányi, G., Siller, J. (Hungary); Kraigher, H., Kutnar, L., Grebenc, T., Jurc, D., Smolej, I., Levaničr T., Rupel, M., (Slovenia); and van Os, B. (The 
Netherlands). In Sweden Örjan Fritz provided much help with the selection of study sites and by supplying information on the management history. Hans Henrik Bruun is thanked for advice on gradient analysis, while Helle Sørensen provided statistical advice. Finally, Ariel Bergamini and two anonymonous referees have provided highly constructive comments on earlier versions of the manuscript. 


\section{References}

Andersson L.I. \& Hytteborn H. (1991) Bryophytes and decaying wood: a comparison between managed and natural forests. Holarctic Ecology, 14, 121-130.

Arcanum (2006) Digitized maps of the Habsburg Empire. The second military survey 18061869. DVD-Rom. Arcanum Kft., Budapest.

Babos, M. (1981) Mycological examination of sawdust depots in Hungary. Studia botanica Hungarica, 15, 31-44.

Bässler, C., Müller, J., Dziock, F. \& Brandl, R. (2010) Effects of resource availability and climate on the diversity of wood-decaying fungi. Journal of Ecology, 98, 822-832.

Berglund, H., Hottola, J., Penttilä, R. \& Siitonen, J. (2011) Linking substrate and habitat requirements of wood-inhabiting fungi to their regional extinction vulnerability. Ecography, 34, 864-875.

Boddy, L. (1999) Saprotrophic cord-forming fungi: meeting the challenge of heterogeneous environments. Mycologia, 91, 13-32.

Boddy, L. \& Heilmann-Clausen, J. (2008) Basidiomycete community development in temperate angiosperm wood. Ecology of Saprotrophic Basidiomycetes (eds. L. Boddy, J.C. Frankland \& P. van West), pp. 211-237. Elsevier.

Bradshaw, R.H.W., Kito, N., Giesecke, T. (2010) Factors influencing the Holocene history of Fagus. Forest Ecology and Management, 259, 2204-2212.

Brunet, J., Fritz, Ö. \& Richnau, G. (2010) Biodiversity in European beech forests - a review with recommendations for sustainable forest management. Ecological Bulletins, 53, 7794.

Christensen, M., Hahn, K., Mountford, E., Ódor, P., Standovár, T., Rozenbergar, D., Diaci, J., Wijdeven, S., Meyer, P., Winter, S. \& Vrska, T. (2005) Dead wood in European beech forest reserves. Forest Ecology and Management, 210, 267-282.

Clausen, E. (1964) The tolerance of hepatics to desiccation and temperature. Bryologist, 67, 411-417.

Fang, J. \& Lechowicz, M.J. (2006) Climatic limits for the present distribution of beech (Fagus L.) species in the world. Journal of Biogeography, 33, 1804-1819.

Frahm, J. P. \& Frey, W. (1992) Mossflora. Ulmer Verlag, Stuttgart.

Fukami, T., \& Wardle, D.A. (2005) Long-term ecological dynamics: reciprocal insights from natural and anthropogenic gradients. Proceedings of the Royal Society B, 272, 2105-2115 
Gignac, L.D. \& Dale, M.R.T. (2005) Effects of fragment size and habitat heterogeneity on cryptogam diversity in the low-boreal forests of Western Canada. The Bryologist, 108, 5066.

Gómez-Hernández, M., Williams-Linera, G., Guevara, R. \& Lodge, D.J. (2012) Patterns of macromycete community assemblage along an elevation gradient: options for fungal gradient and metacommunity analyses. Biodiversity and Conservation, 21, 2247-2268.

Gossner, M.M., Lachat, T., Brunet, J., Isacsson, G., Bouget, C., Brustel, H., Brandl, R., Weisser, W.W. \& Müller, J. (2013) Current "near-to-nature" forest management effects on functional trait composition of saproxylic beetles in beech forests. Conservation Biology 27, 605-614.

Grolle, R. \& Long, D.G. (2000) An annotated check-list of the Hepaticae and Anthocerotae of Europe and Macaronesia. Journal of Bryology 22, 103-140.

Halme, P., Ódor, P., Christensen, M., Piltaver, A., Veerkamp, M., Walleyn, R., Siller, I. \& Heilmann-Clausen, J. 2013. The effects of habitat degradation on metacommunity structure of wood-inhabiting fungi in European beech forests. Biological Conservation 168, 24-30.

Hansen, L. \& Knudsen, H. (eds.), (1992-2000) Nordic Macromycetes, vol I-III. Nordsvamp, Copenhagen.

Heilmann-Clausen, J. (2001) A gradient analysis of communities of macrofungi and slime moulds on decaying beech logs. Mycological Research, 105, 575-596.

Heilmann-Clausen, J. \& Boddy, L. (2008) Distribution patterns of wood decay basidiomycetes at the landscape to global scale. Ecology of Saprotrophic Basidiomycetes (eds. L. Boddy, J.C. Frankland \& P. van West), pp. 263-275. Elsevier.

Heilmann-Clausen, J. \& Christensen, M. (2005) Wood-inhabiting macrofungi in Danish beech-forests - conflicting diversity patterns and their implications in a conservation perspective. Biological Conservation, 122, 633-642.

Heilmann-Clausen, J, Aude, E. \& Christensen, M. (2004) Cryptogam communities on decaying deciduous wood - does tree species diversity matter? Biodiversity and Conservation, 14, 2061-2078.

Hill, M.O. \& Gauch, H.G. (1980) Detrended correspondence analysis, an improved ordination technique. Vegetatio, 42, 47-58.

Hill, M.O., Bell, N., Bruggeman-Nannaenga, M.A., Brugues, M., Cano, M. J., Enroth, J., Flatberg, K.I., Frahm, J. P., Gallego, M.T., Gariletti, R., Guerra, J., Hedenas, L., Holyoak, D.T., Hyvönen, J., Ignatov, M.S., Lara, F., Mazimpaka, V., Munoz, J. \& Söderström, L. 
(2006) An annotated checklist of the mosses of Europe and Macaronesia. Journal of Bryology, 28, 198-267.

Hohenwallner, D., Zechmeister H.G., Moser D., Pauli H., Gottfried M., Reiter K. \& Grabherr, G. (2011) Alpine bryophytes as indicators for climate change: a case study from the Austrian Alps. Bryophyte ecology and climate change (eds. Z. Tuba, N.G. Slack \& L.R. Stark), pp. 237-250. Cambridge University Press, Cambridge.

Jansová, I. (2006) Seasonal growth and dynamics of epixylic bryophytes in Bohemian oldgrowth forest. Journal of Bryology, 28, 123-132.

Jonsson, B. G., Kruys, N. \& Ranius, T. (2005) Ecology of species living on dead wood. Lessons for dead wood management. Silva Fennica, 39, 289-309.

Kaplan, J.O., Krumhardt, K.M. \& Zimmermann, N. (2009) The prehistoric and preindustrial deforestation of Europe. Quaternary Science Reviews, 28, 3016-3034.

Kushnevskaya, H., Denis, M., Shorohova, E. (2007) Patterns of epixylic vegetation on spruce logs in late-successional boreal forests. Forest Ecology and Management, 250, 25-33.

Lachat, T., Wermelinger, B., Gossner, M.M., Bussler, H., Isacsson, G. \& Muller, J. (2012) Saproxylic beetles as indicator species for dead-wood amount and temperature in European beech forests. Ecological Indicators 23, 323-331.

Lassauce, A., Paillet, Y., Jactel, H. \& Bouget, C. (2011) Deadwood as a surrogate for forest biodiversity: metaanalysis of correlations between deadwood volume and species richness of saproxylic organisms. Ecological Indicators 11, 1027-1039.

Lepš, J. \& Šmilauer, P. (2003) Multivariate Analysis of Ecological Data using Canoco. Cambridge University Press, Cambridge, UK.

Lindblad, I. (2001). Diversity of poroid and some corticoid wood inhabiting fungi along the rainfall gradient in tropical forests, Costa Rica. Journal of Tropical Ecology, 17, 353-369.

Löbel, S. \& Rydin, H. (2009) Dispersal and life-history strategies in epiphyte metacommunities: alternative solutions to survival in patchy, dynamic landscapes. Oecologia, 161, 569-579.

Löbel, S., Snäll, T. \& Rydin, H. (2006) Metapopulation processes in epiphytes inferred from patterns of regional distribution and local abundance in fragmented forest landscapes. Journal of Ecology, 94, 856-868.

Logue, J. B. Mouquet, N., Peter, H., Hillebrand, H. \& Metacommunity Working Group. (2011) Empirical approaches to metacommunities: a review and comparison with theory. Trends in Ecology and Evolution, 26, 482-491. 
McAlister, S. (1997) Cryptogam communities on fallen logs in the Duke Forest, North Carolina. Journal of Vegetation Science, 8, 115-124.

McCune, B. \& Mefford, M.J. (1999) Multivariate Analysis of Ecological Data, Version 4.25.

MjM Software, Gleneden Beach, Oregon.

Müller, J. \& Bütler, R. (2010). A review of habitat thresholds for dead wood: a baseline for management recommendations in European forests. European Journal of Forest Research 129, 981-992.

Müller, J., Brunet, J., Brin, A., Bouget, C., Brustel, H., Bussler, H., Förster, B., Isacsson, G., Köhler, F., Lachat, T., Gossner, M.M. (2013) Implications from large-scale spatial diversity patterns of saproxylic beetles for the conservation of European Beech forests. Insect Conservation and Diversity, 6, 162-169.

Nordén, J., Penttilä, R., Siitonen, J., Tomppo, E. and Ovaskainen, O. (2013) Specialist species of wood-inhabiting fungi struggle while generalists thrive in fragmented boreal forests. Journal of Ecology, 101, 701-712.

Ódor, P., Heilmann-Clausen, J., Christensen, M., Aude, E., van Dort, K. W., Piltaver, A., Siller, I., Veerkamp, M. T., Walleyn, R., Standovár, T., van Hees, A. F. M., Kosec, J., Matočec, N., Kraigher, H. \& Grebenc, T. (2006) Diversity of dead wood inhabiting fungi and bryophytes in semi-natural beech forests in Europe. Biological Conservation, 131, 5871.

Ódor, P. \& Standovár, T. (2002) Substrate specificity and community structure of bryophyte vegetation in a near-natural montane beech forest. Community Ecology, 3, 39-49.

Ódor, P. \& van Hees, A.F.M. (2004) Preferences of dead wood inhabiting bryophytes for decay stage, log size and habitat types in Hungarian beech forests. Journal of Bryology, 26, 79-95.

Ódor, P., van Hees, A.F.M, Heilmann-Clausen, J., Christensen, M., Aude, E., van Dort, K.W., Piltaver, A., Siller, I., Veerkamp, M.T., Grebenc, T., Kutnar, L., Standovár, T., Kosec, J., Matočec, N., Kraigher, H. (2004) Ecological succession of bryophytes, vascular plants and fungi on beech coarse woody debris in Europe. Nat-Man working report 51. www.flec.kvl.dk/natman

Økland, R. H. (1999) On the variation explained by ordination and constrained ordination axes. Journal of Vegetation Science, 10, 131-136.

Paltto, H., Nordén, B., Götmark, F. \& Franc, N. (2006) At which spatial and temporal scales does landscape context affect local density of Red Data Book and Indicator species? Biological Conservation, 133, 442-454. 
Penttilä, R., Lindgren, M., Miettinen, O., Rita, H. \& Hanski, I. (2006) Consequences of forest fragmentation for polyporous fungi at two spatial scales. Oikos, 114, 225-240.

Pinheiro, J., Bates, D., DebRoy, S., Sarkar, D. \& The R Development Core Team (2011) nlme: Linear and Nonlinear Mixed Effects Models. R package version 3.1-102.

Rahbek, C. (2005) The role of spatial scale and the perception of large-scale species-richness patterns. Ecology Letters, 8, 224-39

Qian, H., Klinka, K. \& Song, X. (1999) Cryptogams on decaying wood in old-growth forests on southern coastal British Columbia. Journal of Vegetation Science, 10, 883-894.

Raabe, S., Müller, J., Manthey, M., Dürhammer, O., Teuber, U., Göttlein, A., Förster, B., Brandl, R. \& Bässler, C. (2010) Drivers of bryophyte diversity allow implications for forest management with a focus on climate change. Forest Ecology and Management, 260, 1956-1964.

Rambo, T.R. \& Muir, P.S. (1998) Bryophyte species association with coarse woody debris and stand ages in Oregon. The Bryologist, 101, 366-376.

Runge, A. (1975) Pilzsukzession auf Laubholzstümpfen. Zeitschrift für Pilzkunde, 41, 31-38.

Saboljevic, M., Vujicic, M., Saboljevic, A. (2010) Diversity of saproxylic bryophytes in oldgrowth and managed beech forests in the central Balkans. Plant Biosystems, 144, 234-240.

Schmitt, C. B., Burgess, N. D., Coad, L., Belokurov, A., Besançon, C.Boisrobert, L. 2009. Global analysis of the protection status of the world's forests. Biological Conservation, 142: 2122-2130.

Schumacker, R. \& Vana, J. (2005) Identification keys to the liverworts and hornworts of Europe and Macaronesia. Sorus, Poznań, Poland.

Smith, A.J.E. (2004) The moss flora of Britain and Ireland. Cambridge University Press, Cambridge.

Söderström, L. (1988) Sequence of bryophytes and lichens in relation to substrate variables of decaying coniferous wood in Northern Sweden. Nordic Journal of Botany, 8, 89-97.

Stokland, J.N., Siitonen, J. \& Jonsson, B.G. 2012. Biodiversity in dead wood, Cambridge University Press, Cambridge.

Sundqvist, M.K., Sanders, N.J. \& Wardle, D.A. (2013) Community and ecosystem responses to elevational gradients: processes, mechanisms, and insights for global change. Annual Review of Ecology, Evolution, and Systematics, 44, 261-280.

ter Braak, C. J. F. \& Smilauer, P. (2002) Canoco 4.5. Biometris, Wageningen and České Budĕjovice. 
The R Development Core Team (2012). R. 2.15.2. A language and environment for statistical computing. www.r-project.org.

Weiher, E., Freund, D., Bunton, T., Stefanski, A., Lee, T. \& Bentivenga, S. (2011) Advances, challenges, and a developing synthesis of ecological community assembly theory. Philosophical Transactions of the Royal Society B, 366, 2403-2413.

Willner, W., Di Pietro, R. \& Bergmeier, E. (2009) Phytogeographical evidence for postglacial dispersal limitation of European beech forest species. Ecography, 32, 1011-1018.

Zuur, A.F., Ieno, E.N., Walker, N.J., Saveliev, A.A. \& Smith, G. (2009). Mixed effects models and extension in ecology with $R$. Springer, New York.

\section{BIOSKETCH}

This study was initiated as part of a collaborative EU project on Nature Based Management of Beech in Europe (Nat-Man) with the aim to highlight the importance of dead wood for biodiversity across Europe. The fungal dataset was collected by J.H.-C., M.C., A.P., M.V., R.W. and I.S., the bryophyte dataset by P.Ó., E.A. and K.D. J.H.-C. had the lead role in writing the manuscript; analyses were made by J.H.-C. and P.Ó. with considerable contributions from T.S. and E.A. P.Ó. was the coordinator of the field work making the study possible.

Editor: Peter Linder 
Table 1. List of the 26 protected beech stands in Europe, in which fungi and bryophyte communities on fallen beech logs were inventoried for this study. The column 'Abbrev.' lists the site abbreviations shown in in Fig 1.

\begin{tabular}{|c|c|c|c|c|c|c|c|c|c|}
\hline Site name & Abbrev. & $\begin{array}{l}\text { Country } \\
\text { code }^{*}\end{array}$ & $\begin{array}{l}\text { No. of } \\
\text { sampled } \\
\text { logs }\end{array}$ & $\begin{array}{l}\text { Stand } \\
\text { size } \\
\text { (ha) }\end{array}$ & $\begin{array}{l}\text { Dead } \\
\text { wood } \\
\text { volume } \\
\left(\mathrm{m}^{3} / \mathrm{ha}\right)\end{array}$ & $\begin{array}{l}\text { Tree age } \\
(y r s)^{\star \star}\end{array}$ & $\begin{array}{l}\text { Natural- } \\
\text { ness } \\
\text { score* }\end{array}$ & Latitude & Longitude \\
\hline Zoniënwoud, core area & ZOK & B & 125 & 18 & 139 & 220 & 2 & 50.75 & 4.42 \\
\hline \multirow{2}{*}{$\begin{array}{l}\text { Zoniënwoud, buffer zone } \\
\text { Silkeborg Vesterskov, } \\
\text { Knagerne }\end{array}$} & ZON & B & 67 & 80 & 24 & 150 & 1 & 50.75 & 4.42 \\
\hline & KNA & DK & 25 & 6 & 152 & 230 & 2 & 56.13 & 9.53 \\
\hline Møns Klinteskov, Kalsterbjerg & MON & DK & 50 & 25 & 100 & 350 & 2 & 54.96 & 12.54 \\
\hline Strødam & STR & DK & 50 & 25 & 181 & 250 & 2 & 55.97 & 12.27 \\
\hline Suserup Skov & SUS & DK & 50 & 19 & 176 & 350 & 3 & 55.37 & 11.55 \\
\hline Velling Skov & VEL & DK & 25 & 24 & 114 & 275 & 2 & 56.04 & 9.5 \\
\hline Kekes & KEK & $\mathrm{H}$ & 97 & 63 & 99 & 350 & 4 & 47.87 & 20 \\
\hline Õserdõ & OSE & $\mathrm{H}$ & 110 & 25 & 164 & 250 & 2 & 48.05 & 20.43 \\
\hline Krokar & $\mathrm{KRO}$ & SI & 101 & 73 & 153 & 350 & 4 & 45.54 & 14.78 \\
\hline Rajhenavski Rog & RAJ & SI & 110 & 51 & 299 & 350 & 4 & 45.66 & 15.02 \\
\hline Äskemossen & ASK & $\mathrm{S}$ & 25 & 8 & 25 & 200 & 1 & 57.09 & 12.57 \\
\hline Dömestorp & DOM & $S$ & 50 & 18 & 25 & 200 & 1 & 56.41 & 12.98 \\
\hline Biskopstorp, Holkåsen & $\mathrm{HOL}$ & $\mathrm{S}$ & 50 & 6 & 70 & 300 & 2 & 56.8 & 12.89 \\
\hline Biskopstorp, Kvinnsåsen & $\mathrm{KVI}$ & $S$ & 15 & 2 & 25 & 250 & 2 & 56.81 & 12.91 \\
\hline Biskopstorp, N Kroksjön & NKR & $S$ & 25 & 10 & 25 & 250 & 2 & 56.8 & 12.89 \\
\hline Biskopstorp, Trälhultet & TRA & $S$ & 10 & 6 & 25 & 250 & 2 & 56.81 & 12.91 \\
\hline Valaklitt & VAL & $S$ & 25 & 10 & 75 & 250 & 2 & 57.1 & 12.55 \\
\hline Utrecht, Amelisweerd & AMW & $\mathrm{NL}$ & 5 & 3 & 72 & 150 & 1 & 52.1 & 5.18 \\
\hline Veluwe, Dassenberg & $\mathrm{DAB}$ & $\mathrm{NL}$ & 33 & 12 & 63 & 200 & 1 & 52.07 & 5.88 \\
\hline Veluwe, Drie & DRI & $\mathrm{NL}$ & 21 & 5 & 44 & 200 & 1 & 52.07 & 5.88 \\
\hline Veluwe, Gortelsebos & GOB & $\mathrm{NL}$ & 11 & 15 & 66 & 200 & 1 & 52.07 & 5.88 \\
\hline Utrecht, Oostbroek & OOB & $\mathrm{NL}$ & 10 & 3 & 72 & 150 & 1 & 52.1 & 5.18 \\
\hline Veluwe, Speulderbos & SPB & $\mathrm{NL}$ & 42 & 27 & 44 & 200 & 1 & 52.25 & 5.72 \\
\hline Veluwe, Weversbergen & WEB & $\mathrm{NL}$ & 32 & 12 & 49 & 100 & 1 & 52.07 & 5.88 \\
\hline Utrecht, Wulperhorst & WUH & $\mathrm{NL}$ & 44 & 3 & 72 & 200 & 1 & 52.1 & 5.18 \\
\hline
\end{tabular}


Table 2. List of environmental variables recorded in this study on fungi and bryophyte communities on beech logs in Europe, and their affiliation to defined variable sets.

\begin{tabular}{|c|c|c|c|c|}
\hline Variable name & Variable set & Description & Data type & $\begin{array}{l}\text { Min, mean and } \\
\max \end{array}$ \\
\hline DECAY STAGE & Substrate & Average decay stage of $\log ^{*}$ & ordinal, six stages & $1-3.1-6$ \\
\hline $\mathrm{DBH}$ & Substrate & Diameter at breast height & continuous, $\mathrm{cm}$ & 10-56.2-135 \\
\hline BARK COVER & Substrate & Bark cover of log & continuous, \% & 0-38.6-100 \\
\hline SOIL CONTACT & Substrate & Soil contact of log & continuous, \% & $0-71.6-100$ \\
\hline MOSS COVER & Substrate & Moss cover on logT & continuous, \% & 0-24.3-100 \\
\hline SNAG & Substrate & Presence/absence of snag & binary & \\
\hline ELEVATION & Climate and soil & Elevation & continuous, $\mathrm{m}$ & 2-373-1120 \\
\hline TEMP_MIN & Climate and soil & Mean temperature of the coldest month ${ }^{\dagger}$ & continuous, ${ }^{\circ} \mathrm{C}$ & $-4.7--0.4-3.4$ \\
\hline TEMP_MAX & Climate and soil & Mean temperature of the warmest month ${ }^{\dagger}$ & continuous, ${ }^{\circ} \mathrm{C}$ & $15.5-16.6-18.2$ \\
\hline TEMP_RANGE & Climate and soil & $\begin{array}{l}\text { Temperature difference between coldest and } \\
\text { warmest month }^{\dagger}\end{array}$ & continuous, ${ }^{\circ} \mathrm{C}$ & $14.4-17.0-20.2$ \\
\hline TEMP_AVE & Climate and soil & Mean annual temperate ${ }^{\dagger}$ & continuous, ${ }^{\circ} \mathrm{C}$ & $5.7-7.82-9.4$ \\
\hline PRECIPITATION & Climate and soil & Mean annual precipitation ${ }^{\dagger}$ & continuous, mm & $586-988-1579$ \\
\hline SNOW COVER & Climate and soil & Mean number of days per year with snow cover $^{\dagger}$ & continuous, days & 25-68.3-140 \\
\hline LANG'S RAINFALL INDEX & Climate and soil & $\begin{array}{l}\text { Mean annual precipitation/mean annual } \\
\text { temperature }\end{array}$ & continuous, $\mathrm{mm} /{ }^{\circ} \mathrm{C}$ & $\begin{array}{l}74.2-130.4- \\
205.1\end{array}$ \\
\hline SOIL_RICH & Climate and soil & Soil richness ${ }^{\ddagger}$ & ordinal, four stages & $1-2.7-4$ \\
\hline NATURALNESS & Forest conditions & Naturalness of the stand as a forest $t^{\pi}$ & ordinal, four stages & $1-2.3-4$ \\
\hline TREE AGE & Forest conditions & Highest age of the dominant trees & continuous, year & $100-262.7-300$ \\
\hline STAND SIZE & Forest conditions & Area of the strict forest reserve & continuous, hectar & $2.2-31.5-80$ \\
\hline CWD VOLUME & Forest conditions & Volume of dead wood in the reserve $e^{\S}$ & continuous, $\mathrm{m}^{3} \cdot \mathrm{ha}^{-1}$ & 24-119.5-299 \\
\hline FOREST COVER & Forest conditions & Present forest cover, $5 \mathrm{~km}$ radius ${ }^{* *}$ & continuous, \% & $9.4-61.2-98.2$ \\
\hline DECIDUOS COVER & Forest conditions & Present cover of deciduous forest, $5 \mathrm{~km}$ radius ${ }^{* *}$ & continuous, \% & 0.9-32.4-95.5 \\
\hline CONIFEROUS COVER & Forest conditions & Present cover of coniferous forests, $5 \mathrm{~km}$ radius & continuous, \% & $0-16.2-66.6$ \\
\hline CONIFEROUS SHARE & Forest conditions & Present coniferous forest share* & continuous, \% & $0-27.6-83$ \\
\hline PAST FOREST COVER & Forest conditions & Past forest cover, $5 \mathrm{~km}$ radius ${ }^{\dagger \dagger}$ & continuous, \% & $0-58.1-90$ \\
\hline FOREST COVER CHANGE & Forest conditions & Change in forest cover, $5 \mathrm{~km}$ radius ${ }^{\ddagger \ddagger}$ & continuous, \% & $-41.5-3.1-43.9$ \\
\hline
\end{tabular}

Based on Ódor \& van Hees (2004); ${ }^{\dagger}$ Based on data from smhi.se, normals 1961-1990 (S), dmi.dk, normals 1961-1990 (DK), knmi.nl, normals 1971-2000 (NL), meteo.be, normal 1971-2000(B), met.hu, normals 1971-2000 (H), meteo.arso.gov.si, normals 1971-2000 (SI); ${ }_{\ddagger_{1}}$ : sand (NL, DK), granite (S); 2: loam-sand and clay (NL); 3: sand-clay and loam-sand (DK), andesite (H), loess (B); 4: limestone (SL, $\mathrm{H}$ ), chalk (DK); ${ }^{\pi}$ : Recently managed forests with a homogenous structure and low levels of dead wood, dominant trees generally $=<$ $200 \mathrm{yrs}$, gaps in tree continuity possible; 2: Recently managed forests with a homogenous structure and moderate levels of dead wood, dominant trees generally > $200 \mathrm{yrs}$, no gaps in tree continuity; 3 : Forests affected by selective cuttings in the past, but with a heterogeneous structure and abundant dead wood; dominant trees generally > 200 yrs, no gaps in tree continuity; 4: More or less virgin

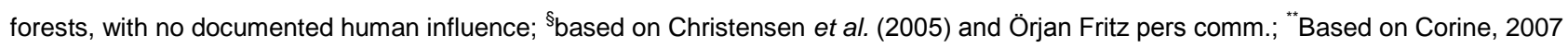
data; ${ }^{\dagger}$ Based on Videnskabernes Selskab kort 1762-1820 (DK); Generalstabens karta över Halland 1839-1842 (S); Nieuwe Geographische Reise- en Zak-Atlas, Jan Christiaan Sepp 1773 (NL); Plan Topographique de la Ville de Bruxelles, Joseph de Ferraris, 1777 (B); Second Military Survey of the Habsburg Empire 1806-1869 (Arcanum 2006, H and SI); ${ }^{\ddagger}$ Present forest cover minus past forest cover. 
Table 3. Simple mixed-effects models between environmental variables and DCA ordination axis scores based on bryophytes and fungal communities using site as a random factor. For substrate variables the degree of freedom was 862 for bryophytes and 933 for fungi. For site level variables (Climate and soil, forest conditions) the degree of freedoms was 22 in both groups. For each variable the direction of the effect (+ or - sign) and the F-value is given.

\begin{tabular}{|c|c|c|c|c|c|c|c|c|c|c|c|c|c|}
\hline & \multirow[b]{2}{*}{ Variable set } & \multicolumn{6}{|c|}{ Bryophytes } & \multicolumn{6}{|c|}{ Fungi } \\
\hline & & $\begin{array}{l}\text { Axis } \\
\text { sign }\end{array}$ & $\begin{array}{l}1 \\
F\end{array}$ & $\begin{array}{l}\text { Axis } \\
\text { sign }\end{array}$ & $\begin{array}{l}2 \\
F\end{array}$ & $\begin{array}{l}\text { Axis } \\
\text { sign }\end{array}$ & $\begin{array}{l}3 \\
\mathrm{~F}\end{array}$ & $\begin{array}{l}\text { Axis } \\
\text { sign }\end{array}$ & 1 & $\begin{array}{l}\text { Axis } \\
\text { sign }\end{array}$ & & $\begin{array}{l}\text { Axis } 3 \\
\text { sign } \\
\end{array}$ & $\mathrm{F}$ \\
\hline DECAY STAGE & Substrate & + & $31.1^{* \star \star *}$ & - & $216.1^{\text {****}}$ & + & $342.9^{* \star \star *}$ & - & $1441.2^{* * * *}$ & - & $24.1^{* *}$ & + & $10.1^{\star \star}$ \\
\hline $\mathrm{DBH}$ & Substrate & - & 7.2 & + & 11.6 & - & $10.3^{\star \star}$ & + & 0 & + & 0 & - & $22.5^{\star \star \star \star}$ \\
\hline BARK COVER & Substrate & - & $26.7^{\star \star}$ & + & $169.1^{\star * * *}$ & - & $244^{\star * \star *}$ & + & $873.2^{\star * * *}$ & + & $19.5^{\star *}$ & - & $15.2^{\star \star \star}$ \\
\hline SOIL CONTACT & Substrate & + & $16.9^{* * * *}$ & - & $86.6^{\star \star * *}$ & + & $184.7^{* \star * *}$ & - & $370.4^{* * * *}$ & - & $7.7^{\star}$ & + & 3.8 \\
\hline MOSS COVER & Substrate & + & 1.6 & - & 7.5 & + & $93.7^{\star \star \star \star}$ & - & $118.9^{* \star \star *}$ & - & $8.8^{*}$ & - & 3.4 \\
\hline ELEVATION & Climate and soil & - & $61.3^{* * * *}$ & - & 0 & - & 2.1 & + & 0.1 & + & $44.2^{* * * *}$ & - & 1.5 \\
\hline TEMP_MIN & Climate and soil & + & $19.5^{\star *}$ & - & 6.5 & - & 0.5 & + & 0.6 & - & $87.3^{\star * * *}$ & + & 0 \\
\hline TEMP_MAX & Climate and soil & + & 0.8 & - & $17.4^{* *}$ & - & 3.3 & + & 0.8 & - & 7 & - & 0.7 \\
\hline TEMP_RANGE & Climate and soil & - & $48.9^{* * \star *}$ & + & 1.6 & + & 0 & - & 0.3 & + & $151.9^{* * * *}$ & - & 0.39 \\
\hline TEMP_AVE & Climate and soil & + & 6 & - & $11.5^{*}$ & - & 3.7 & + & 1.6 & - & $22^{\star \star}$ & + & 0 \\
\hline PRECIPITATION & Climate and soil & - & 5.7 & + & 3.1 & + & 1.2 & + & 5 & + & 2.6 & - & 3.2 \\
\hline SNOW COVER & Climate and soil & - & $52.1^{* * * *}$ & + & 1.8 & + & 0 & + & 0 & + & $41.1^{* * * *}$ & - & 2.3 \\
\hline $\begin{array}{l}\text { LANG'S } \\
\text { RAINFALL } \\
\text { INDEX }\end{array}$ & Climate and soil & & & & & & & & & & & & \\
\hline $\begin{array}{l}\text { INDEX } \\
\text { SOIL_RICH }\end{array}$ & Climate and soil & $\begin{array}{l}- \\
-\end{array}$ & $\begin{array}{l}8.6 \\
22.5^{\star *}\end{array}$ & $\begin{array}{l}+ \\
-\end{array}$ & $\begin{array}{l}10 \\
6.1\end{array}$ & $\begin{array}{l}+ \\
-\end{array}$ & $\begin{array}{l}3.7 \\
1.2\end{array}$ & $\begin{array}{l}+ \\
-\end{array}$ & $\begin{array}{l}0.9 \\
4.1\end{array}$ & $\begin{array}{l}+ \\
+\end{array}$ & $\begin{array}{l}11 \\
7.7\end{array}$ & $\begin{array}{l}- \\
-\end{array}$ & $\begin{array}{l}2 \\
0.7\end{array}$ \\
\hline NATŪRALNESS & Forest conditions & - & $53.2^{* * * *}$ & + & 0.2 & - & 0.5 & - & 0.8 & + & $25.9^{\star * *}$ & - & 2 \\
\hline TREE AGE & Forest conditions & - & $24.4^{* *}$ & + & 2.9 & - & 0.1 & - & 2.5 & + & $20.4^{\star \star}$ & + & 0 \\
\hline STAND SIZE & Forest conditions & - & 10.3 & - & 3.9 & - & 0.8 & - & 0 & + & 3.7 & - & 0.5 \\
\hline CWD VOLUME & Forest conditions & - & $17.5^{\star \star}$ & - & 1.1 & - & 1 & - & 1.7 & + & 4.6 & - & 2.8 \\
\hline $\begin{array}{l}\text { FOREST } \\
\text { COVER }\end{array}$ & Forest conditions & - & 8.4 & + & 4 & + & 0.2 & + & 0.8 & + & $16.7^{* *}$ & - & 1.2 \\
\hline & Forest conditions & - & $13.2^{*}$ & - & 0.8 & - & 0.8 & - & 2 & + & $27.8^{\star \star \star}$ & - & 1.1 \\
\hline & Forest conditions & + & 2.4 & + & $24.3^{\star *}$ & + & 4.1 & + & 4.3 & - & 0.3 & + & 0 \\
\hline $\begin{array}{l}\text { CONIFEROUS } \\
\text { SHARE }\end{array}$ & Forest conditions & + & 10.35 & + & 10.93 & + & 1.42 & + & 9.91 & - & 2.68 & + & 0.49 \\
\hline $\begin{array}{l}\text { PAST FOREST } \\
\text { COVER } \\
\text { FOREST }\end{array}$ & Forest conditions & - & $11.9^{*}$ & - & 0.9 & - & 0 & - & 1.4 & + & 8.1 & - & 5.6 \\
\hline $\begin{array}{l}\text { COVER } \\
\text { CHANGE }\end{array}$ & Forest conditions & + & 0.3 & + & $15.7^{*}$ & + & 0.4 & + & 7.1 & + & 0.2 & + & 1.8 \\
\hline LATITUDE & Not included & + & $7.8^{*}$ & + & 9.2 & + & 8.4 & - & 0.6 & - & 3.3 & + & 1.8 \\
\hline LONGITUDE & Not included & - & $33.3^{* * *}$ & + & 3.5 & + & 0.1 & - & 1.7 & + & $183.2^{\star * * *}$ & - & 0 \\
\hline
\end{tabular}




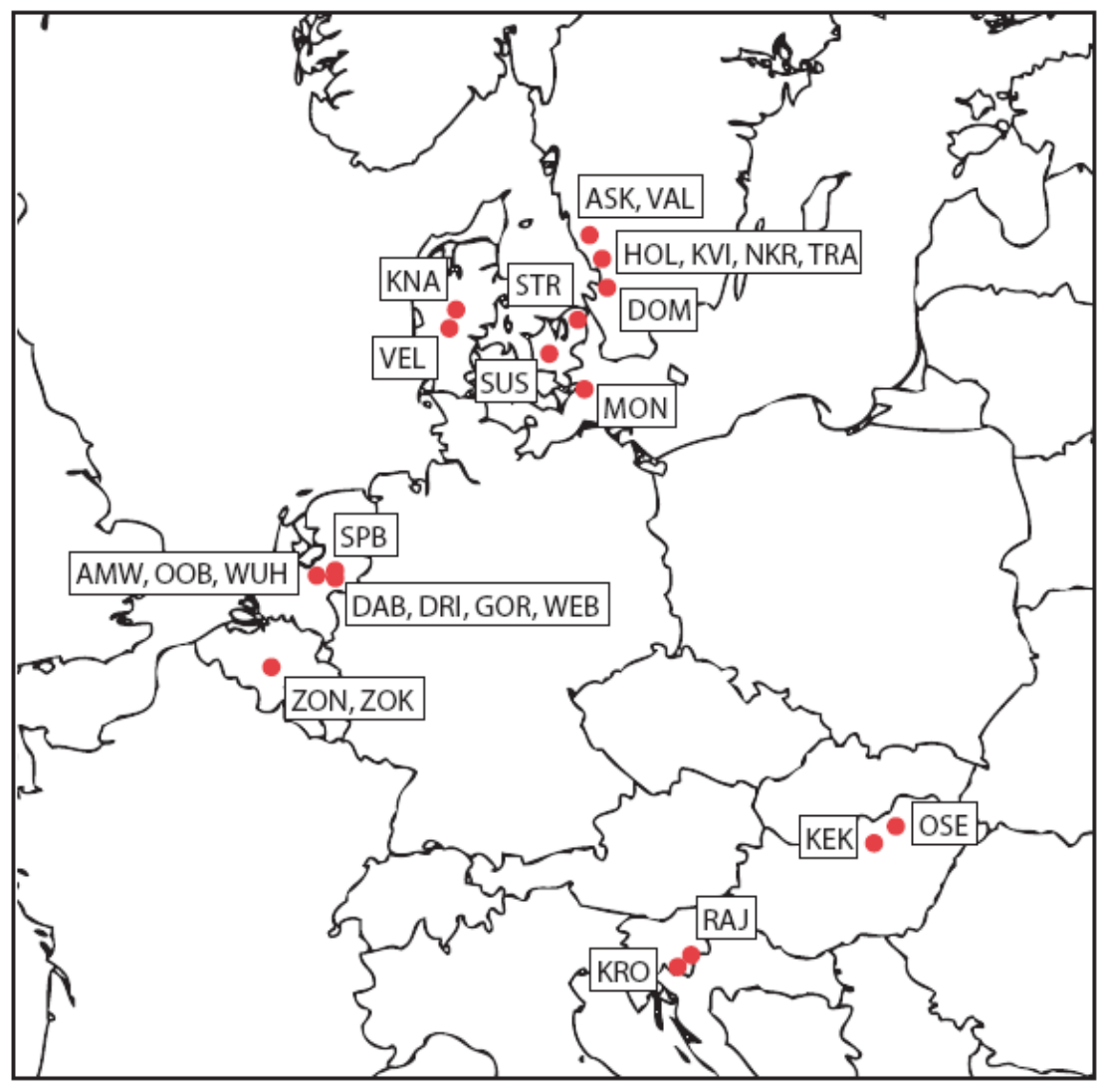

Fig. 1. Map showing the location of 26 protected beech stands in which fungi and bryophyte communities on fallen beech logs were inventoried for this study. For full names of stands, see Table 1. 


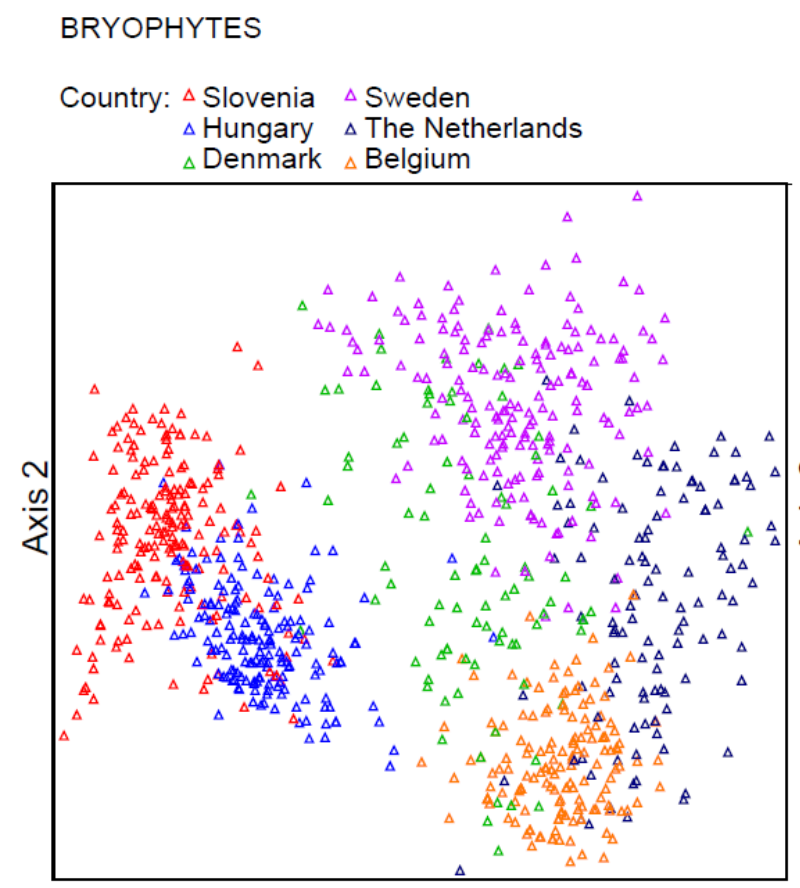

Axis 1
FUNGI

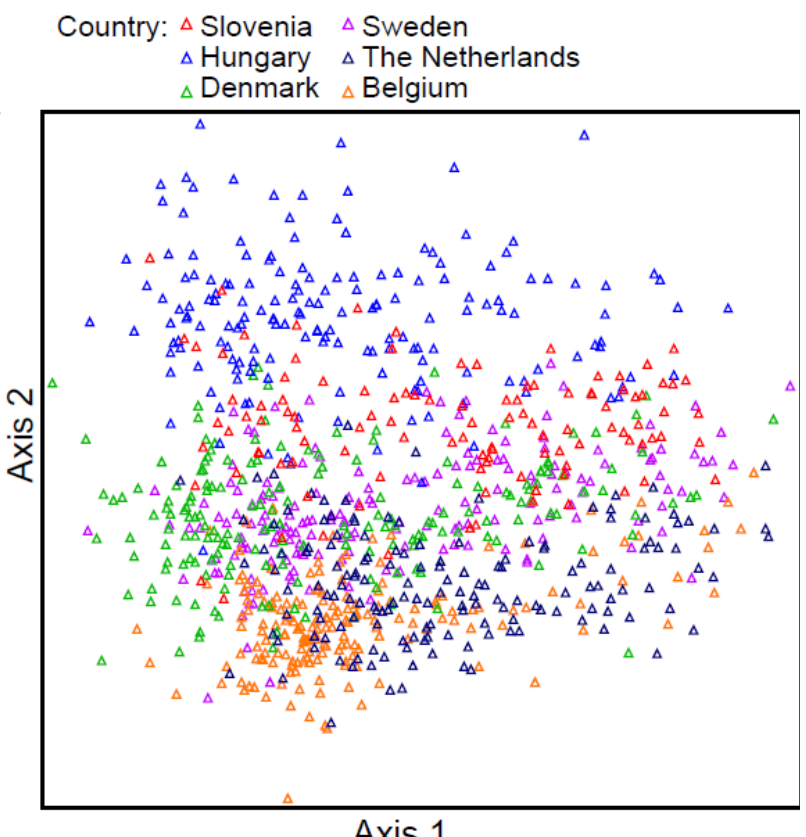

Axis 1

Fig. 2. Diagrams showing the position of sampling units (beech logs) in the ordination space defined by axis 1 and 2 of the DCA based on the bryophyte dataset (left column; 893 logs) and fungal dataset (right column; 965 logs) collected from 26 sites in Europe. The samples (logs) are colour coded according to country. 

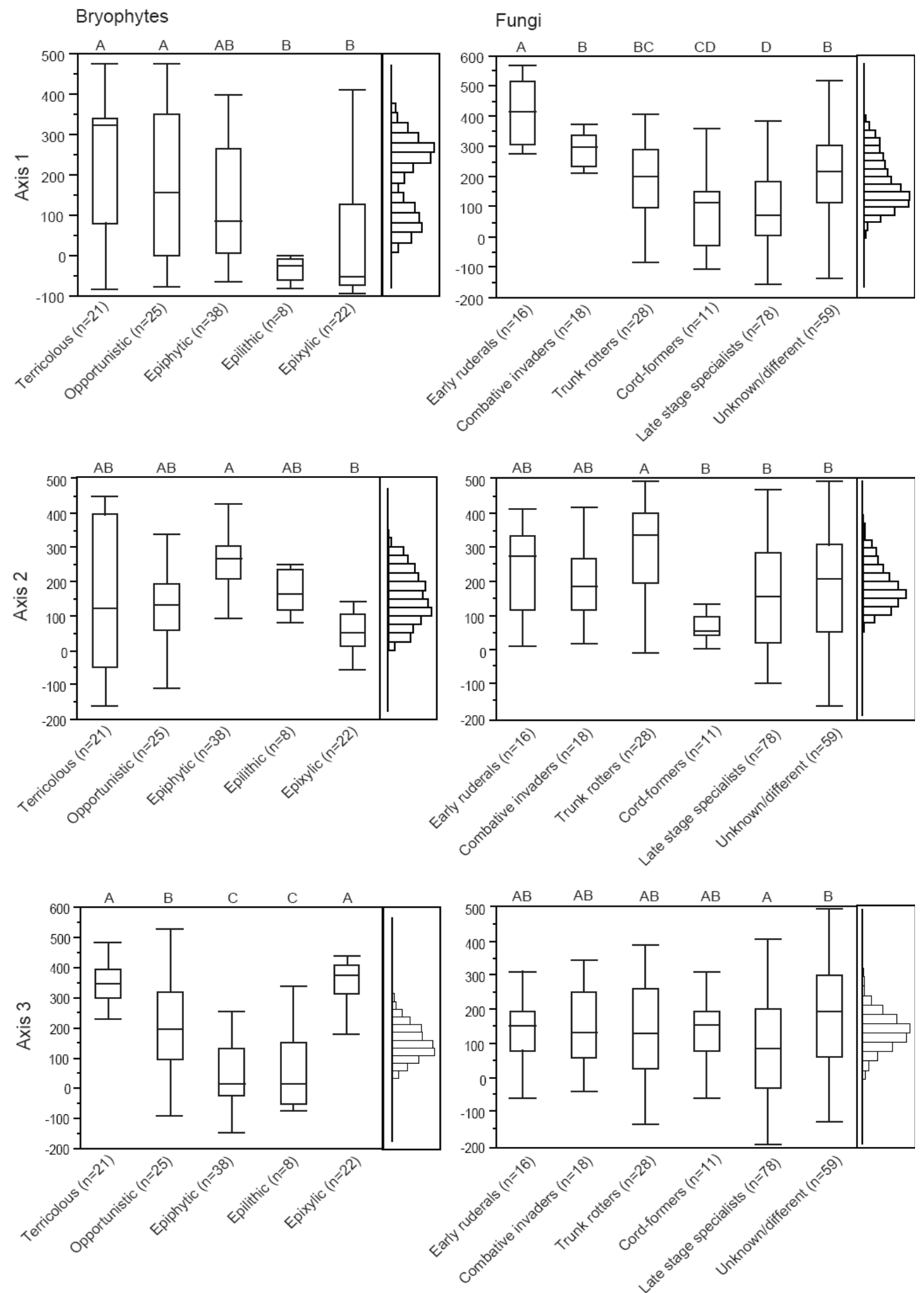

Fig. 3. Boxplots showing the distribution of defined ecological guilds along ordination axes extracted in the DCA based on the bryophyte dataset (left panel) and fungal dataset (right panel) collected from 26 sites in Europe. Different letters indicate significantly different means $(\mathrm{p}<0.05)$ based on Tukey's HSD tests comparing all means. Side-bars show the distribution of samples (logs) along the same ordination axes. 

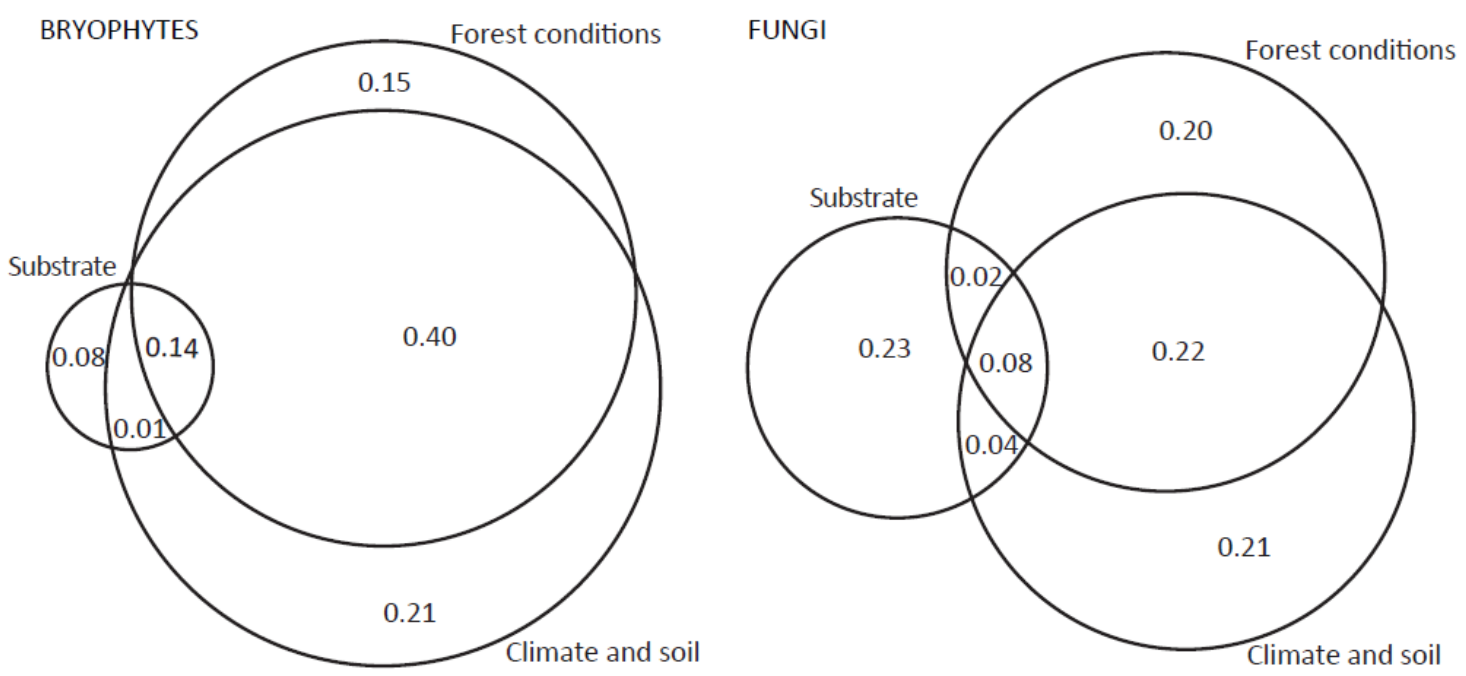

Fig. 4. Venn diagrams, showing the relative contribution of substrate, forest condition and climate variables in explaining variance in the CCAs for bryophytes (left; 893 logs) and fungi (right; 965 logs) on fallen beech logs across 26 sites in Europe. The circles are scaled to show their overall contribution to the explained variance in each dataset, with overlapping areas scaled to show the approximate level of shared contribution for each combination of variable sets. 
Appendix S1: Descriptions of fungal guilds in dead wood, as classified for this study on fungal communities on beech logs in European forest reserves.

\begin{tabular}{|c|c|c|}
\hline Guild & Strategy & $\begin{array}{l}\text { Classification in Boddy \& Heilmann- } \\
\text { Clausen (2008) }\end{array}$ \\
\hline Early ruderals & $\begin{array}{l}\text { Ruderal fungi with weak combative abilities, } \\
\text { causing white rot in wood and bark in early } \\
\text { decay stages, often more common on branches, } \\
\text { than on logs; establishment via latent invasion } \\
\text { in living wood, or via spores on freshly exposed } \\
\text { dead wood; fruit bodies very tolerant to } \\
\text { desiccation; mainly corticoids and } \\
\text { heterobasidiomycetes. }\end{array}$ & $\begin{array}{l}\text { Ruderal primary colonizers and } \\
\text { natural pruners + desiccation and } \\
\text { heat and desiccation tolerant } \\
\text { secondary invaders }\end{array}$ \\
\hline Combative invaders & $\begin{array}{l}\text { Combative fungi causing rapid white rot in early } \\
\text { to intermediate decay stages; equally common } \\
\text { on logs and branches; establishing via latent } \\
\text { invasion in living wood, or from establishment } \\
\text { via spores in recently dead wood; fruit bodies } \\
\text { tolerant to desiccation; mainly polypores. }\end{array}$ & Secondary, combative invaders \\
\hline Cord formers & $\begin{array}{l}\text { Very combative fungi causing white rot in } \\
\text { intermediate to late decay stages; found on } \\
\text { many types of dead wood, sometimes on other } \\
\text { litter; establishing via mycelial cords; fruit } \\
\text { bodies tolerant to desiccation or not; mainly } \\
\text { agarics and gastromycetes. }\end{array}$ & Cord formers \\
\hline Trunk rotters & $\begin{array}{l}\text { Combative or stress tolerant fungi causing } \\
\text { white or brown rot in wood in early to late } \\
\text { decay stages; fruit bodies more or less } \\
\text { restricted to logs; establishment via latent } \\
\text { invasion or heart rot in living trees or via } \\
\text { infection in standing dead trees; fruit bodies } \\
\text { relatively tolerant to desiccation; mainly } \\
\text { polypores and agarics. }\end{array}$ & Heart rot agents \\
\hline Late stage specialists & $\begin{array}{l}\text { Fungi causing white rot or utilizing residual } \\
\text { compounds from previous decay, and restricted } \\
\text { to wood in advanced stages of decay; fruit } \\
\text { bodies found on several types of dead wood; } \\
\text { establishing by airborne spores in already } \\
\text { decayed wood; fruit bodies mainly sensitive to } \\
\text { desiccation; mainly agarics. }\end{array}$ & Late stage polypores and agarics \\
\hline Unknown/different & $\begin{array}{l}\text { Species with unknown or different strategies in } \\
\text { dead wood, including mycoparasites }\end{array}$ & \\
\hline
\end{tabular}


Boddy, L. \& Heilmann-Clausen, J. (2008) Basidiomycete community development in temperate angiosperm wood. Ecology of Saprotrophic Basidiomycetes (eds. L. Boddy, J.C. Frankland \& P. van West), pp. 211-237. Elsevier. 
Appendix S2: Species included in the final dataset, their classification in ecological guilds and scores in the ordinations.

\section{Fungi}

\begin{tabular}{|c|c|c|c|c|}
\hline Species & Guild & dca1 & dca2 & dca3 \\
\hline Annulohypoxylon cohaerens (Pers.) Y.M. Ju, J.D. Rogers \& H.M. Hsieh & Unknown/different & 353.69 & 53.67 & 191.17 \\
\hline Annulohypoxylon multiforme (Fr.) Y.M. Ju, J.D. Rogers \& H.M. Hsieh & Unknown/different & 311.54 & 309.83 & 110.04 \\
\hline Antrodiella hoehnelii (Bres.) Niemelä & Unknown/different & 255.92 & 330.16 & 284.76 \\
\hline Antrodiella semisupina (Berk. \& M.A. Curtis) Ryvarden & Unknown/different & 184.97 & 133.28 & 335.96 \\
\hline Armillaria gallica Marxm. \& Romagn. & Cord & 111.57 & 23.60 & -30.27 \\
\hline Armillaria mellea (Vahl: Fr.) P.Kumm. & Trunk rotters & 193.12 & 331.58 & -63.26 \\
\hline Armillaria ostoyae (Romagn.) Herink & Cord & 353.62 & -27.38 & 282.56 \\
\hline Arrhenia epichysium (Pers.) Redhead, Lutzoni, Moncalvo \& Vilgalys & Late stage specialist & 19.95 & 328.37 & 186.25 \\
\hline Ascocoryne cylichnium (Tul.) Korf & Late stage specialist & 152.01 & 40.46 & 153.38 \\
\hline Ascocoryne sarcoides (Jacq.: Fr.) Groves \& Wilson & Unknown/different & 428.63 & 118.75 & 174.45 \\
\hline Ascocoryne sp. & Unknown/different & 173.64 & 85.12 & 300.02 \\
\hline Ascotremella faginea (Peck) Seaver & Unknown/different & 297.11 & -15.70 & 196.36 \\
\hline Auricularia auricula-judae (Bull.: Fr.) Wettst. & Early ruderals & 348.81 & 325.14 & 267.50 \\
\hline Auricularia mesenterica (Dicks.) Pers. & Unknown/different & 220.74 & 481.34 & 52.35 \\
\hline Biscogniauxia nummularia (Bull.: Fr.) O.K. & Unknown/different & 299.36 & 277.36 & 315.83 \\
\hline Bjerkandera adusta (Willd.: Fr.) P.Karst. & Combative invader & 346.47 & 220.04 & 77.31 \\
\hline Bjerkandera fumosa (Pers.: Fr.) P.Karst. & Combative invader & 331.70 & 95.15 & 101.40 \\
\hline Bolbitius reticulatus (Pers.: Fr.) Rick. & Late stage specialist & 30.79 & 198.68 & 66.41 \\
\hline Bulgaria inquinans (Pers.: Fr.) Fr. & Unknown/different & 513.89 & 201.33 & 202.08 \\
\hline Byssomerulius corium (Persoon) Parmasto & Early ruderals & 405.68 & 399.84 & 260.64 \\
\hline Calocera cornea (Batsch: Fr.) Fr. & Unknown/different & 310.04 & 238.01 & 78.53 \\
\hline Camarops lutea (Alb. \& Schw.) Nannf. & Unknown/different & 61.03 & -115.04 & 492.09 \\
\hline Camarops polysperma (Mont.) Miller & Trunk rotters & -83.76 & 243.85 & 347.03 \\
\hline Camarops tubulina (Alb. \& Schw.) Shear & Trunk rotters & 46.84 & 170.04 & 361.59 \\
\hline Ceriporia excelsa (Lund.) Parm. & Late stage specialist & 201.79 & 206.87 & 154.72 \\
\hline Ceriporia purpurea (Fr.) Donk & Late stage specialist & 222.64 & 399.09 & 39.78 \\
\hline Ceriporia reticulata (Hoffm.: Fr.) Dom. & Late stage specialist & 41.12 & 336.80 & 357.59 \\
\hline Ceriporiopsis gilvescens (Bres.) Dom. & Late stage specialist & 170.71 & 233.59 & -38.31 \\
\hline Cerrena unicolor (Bull.: Fr.) Murr. & Combative invader & 274.98 & 408.08 & 331.20 \\
\hline Chlorociboria aeruginascens (Nyl.) Kanouse & Unknown/different & -187.26 & 83.45 & 393.98 \\
\hline Chondrostereum purpureum (Pers.: Fr.) Pouz. & Early ruderals & 542.86 & 64.92 & 145.32 \\
\hline Clitopilus hobsonii (Berk.) P.D.Orton & Unknown/different & 231.36 & 23.80 & 297.44 \\
\hline Clitopilus scyphoides (Fr.: Fr.) Singer & Unknown/different & -9.52 & -110.90 & -165.21 \\
\hline Conocybe subpubescens P.D.Orton & Late stage specialist & 39.83 & 34.04 & -72.05 \\
\hline Coprinellus disseminatus (Pers.) J.E. Lange & Late stage specialist & 254.90 & 72.95 & 41.74 \\
\hline Coprinellus micaceus (Bull.) Vilgalys, Hopple \& Jacq. Johnson & Cord & 184.61 & 69.37 & 1.49 \\
\hline Coprinellus radians (Desmazières) Vilgalys, Hopple \& Jacq. Johnson & Unknown/different & 222.64 & 359.22 & 60.57 \\
\hline Coprinellus tardus (P. Karsten) P. Karsten & Unknown/different & 206.06 & 462.09 & 209.96 \\
\hline Coprinopsis laanii (Kits van Wav.) Redhead, Vilgalys \& Moncalvo & Late stage specialist & 100.61 & -46.78 & -240.45 \\
\hline Coprinopsis lagopides (P. Karst.) Redhead, Vilgalys \& Moncalvo & Late stage specialist & 32.36 & 150.29 & -164.64 \\
\hline
\end{tabular}


Coprinopsis lagopus (Fr.) Redhead, Vilgalys \& Moncalvo

Crepidotus applanatus (Pers.) P.Kumm.

Crepidotus lundellii Pilat

Crepidotus mollis (Schaeff.: Fr.) Staude

Crepidotus versutus (Peck) Sacc.

Datronia mollis (Sommerf.: Fr.) Donk

Delicatula integrella (Pers.: Fr.) Pat.

Dentipellis fragilis (Pers.: Fr.) Donk

Discina parma J.Breitenb. \& Maas Geest.

Eutypa spinosa (Pers.: Fr.) Tul. \& C.Tul.

Exidia nucleata (Schwein.) Burt.

Exidia nigricans (With.) P. Roberts

Flammulaster limulatus (Fr.) Watling

Flammulina velutipes (Curt.: Fr.) P.Karst.

Fomes fomentarius (L.: Fr.) Fr.

Fomitopsis pinicola (Swartz: Fr.) P.Karst.

Fuscoporia ferrea (Pers.) G. Cunn.

Fuscoporia ferruginosa (Schrad.) Murrill

Galerina marginata (Batsch) Kuhner

Galerina triscopa (Fr.) Kuhner

Ganoderma lipsiensis (Batsch) Atk.

Ganoderma pfeifferi Bres.

Gelatoporia pannocincta (Romell) Niemelä

Gymnopilus sapineus (Fr.: Fr.) Maire

Henningsomyces candidus (Pers.: Fr.) O.K.

Hericium coralloides (Scop.: Fr.) Pers.

Hohenbuehelia auriscalpium (Maire) Singer

Hohenbuehelia fluxilis (Fr.: Fr.) P.D. Orton

Hyphodontia radula (Pers.: Fr.) E.Langer \& Vesterh.

Hypholoma capnoides (Fr.: Fr.) P.Kumm.

Hypholoma fasciculare (Huds.: Fr.) P.Kumm.

Hypholoma lateritium (Schaeff.: Fr.) P.Kumm.

Hypocrea citrina (Pers.: Fr.) Fr.

Hypocrea gelatinosa (Tode: Fr.) Fr.

Hypoxylon fragiforme (Pers.: Fr.) Kickx

Hypoxylon macrocarpum Pouz.

Hypoxylon rubiginosum (Pers.: Fr.) Fr.

Inonotus cuticularis (Bull.: Fr.) P.Karst.

Inonotus obliquus (Pers.: Fr.) Pilat

Ischnoderma resinosum (Schrad.: Fr.) P.Karst.

Kretzschmaria deusta (Hoffm.) P.M.D. Martin

Kuehneromyces mutabilis (Schaeffer) Singer \& A.H. Smith

Laxitextum bicolor (Pers.: Fr.) Lentz

Lentaria epichnoa (Fr.) Corner

Lentinellus cochleatus (Pers.: Fr.) P.Karst.

Lenzites betulinus (L.: Fr.) Fr.

\begin{tabular}{|c|c|c|c|}
\hline Late stage specialist & 190.76 & 457.72 & 228.59 \\
\hline Late stage specialist & 152.97 & 342.66 & -20.74 \\
\hline Unknown/different & 259.89 & 485.74 & 173.42 \\
\hline Unknown/different & 264.34 & 189.24 & -20.47 \\
\hline Late stage specialist & 297.16 & 61.45 & -46.77 \\
\hline Combative invader & 349.75 & 260.58 & 62.73 \\
\hline Late stage specialist & 54.09 & -74.79 & -148.80 \\
\hline Trunk rotters & 46.72 & 337.21 & 249.83 \\
\hline Late stage specialist & -39.30 & 392.69 & -171.05 \\
\hline Unknown/different & 173.68 & 204.27 & 144.69 \\
\hline Early ruderals & 291.95 & 12.40 & 145.94 \\
\hline Early ruderals & 430.01 & 298.08 & 44.60 \\
\hline Late stage specialist & -10.22 & 403.30 & 89.14 \\
\hline Unknown/different & 399.12 & 306.18 & -56.75 \\
\hline Trunk rotters & 257.66 & 243.92 & 187.75 \\
\hline Trunk rotters & 286.47 & 215.68 & 112.46 \\
\hline Unknown/different & -44.74 & 139.21 & 373.17 \\
\hline Unknown/different & 3.12 & 348.32 & 243.53 \\
\hline Late stage specialist & 46.26 & 192.85 & 102.65 \\
\hline Late stage specialist & -140.31 & 88.47 & -140.67 \\
\hline Trunk rotters & 194.71 & 135.02 & 68.56 \\
\hline Trunk rotters & 243.07 & 259.08 & 359.24 \\
\hline Trunk rotters & -5.78 & 394.33 & 168.20 \\
\hline Late stage specialist & 142.35 & -66.19 & 140.23 \\
\hline Late stage specialist & -74.95 & -0.69 & 136.23 \\
\hline Trunk rotters & 57.99 & 356.37 & 259.76 \\
\hline Late stage specialist & -79.76 & -6.17 & 47.82 \\
\hline Early ruderals & 281.63 & 266.55 & -94.88 \\
\hline Unknown/different & 237.35 & 5.01 & 320.13 \\
\hline Late stage specialist & 105.43 & 323.28 & -172.02 \\
\hline Cord & 144.78 & 25.52 & 99.59 \\
\hline Late stage specialist & 85.53 & 113.50 & 270.84 \\
\hline Unknown/different & 218.18 & -73.89 & 385.36 \\
\hline Unknown/different & 114.11 & 279.63 & 13.64 \\
\hline Early ruderals & 422.74 & 134.69 & 173.23 \\
\hline Unknown/different & -16.32 & 195.65 & 401.02 \\
\hline Unknown/different & 212.49 & 0.66 & 364.90 \\
\hline Trunk rotters & 287.77 & 438.33 & 225.04 \\
\hline Trunk rotters & 114.34 & 493.78 & 100.92 \\
\hline Trunk rotters & 217.33 & 392.01 & 122.43 \\
\hline Trunk rotters & 86.73 & 212.31 & 112.14 \\
\hline Late stage specialist & 166.28 & -21.88 & -47.19 \\
\hline Combative invader & 278.84 & 76.26 & 240.64 \\
\hline Late stage specialist & -45.99 & 204.83 & -58.71 \\
\hline Late stage specialist & 383.17 & 438.19 & 139.62 \\
\hline Combative invader & 227.36 & 350.49 & 8.77 \\
\hline
\end{tabular}


Lycoperdon perlatum Pers.: Pers.

Lycoperdon pyriforme Schaeff.: Pers.

Marasmius rotula (Scop.: Fr.) Fr.

Megacollybia platyphylla (Pers.: Fr.) Kotl. \& Pouz.

Meripilus giganteus (Pers.: Fr.) P.Karst.

Multiclavula mucida (Pers.) R.H. Petersen

Mutinus caninus (Huds.: Pers.) Fr.

Mycena abramsii (Murr.) Murr.

Mycena acicula (Schaeff.: Fr.) P.Kumm.

Mycena adscendens (Lasch) Maas Geest.

Mycena arcangeliana Bres.

Mycena crocata (Schrad.: Fr.) P.Kumm.

Mycena erubescens Höhn.

Mycena galericulata (Scop.: Fr.) Quél.

Mycena haematopus (Pers.: Fr.) P.Kumm.

Mycena hiemalis (Osb.: Fr.) Qu $\square$ I.

Mycena olida Bres.

Mycena picta (Fr.: Fr.) Harm.

Mycena polygramma (Bull.: Fr.) Gray

Mycena pseudocorticola Kuhn.

Mycena renati Quél.

Mycena speirea (Fr.: Fr.) Gillet

Mycena tintinabulum (Fr.) Quél.

Mycena vitilis (Fr.) Quél.

Mycoacia aurea (Fr.) J. Erikss. \& Ryvarden

Mycoacia uda (Fr.) Donk

Mycetinis alliaceus (Jacquin) Earle

Nemania atropurpurea (Fr.: Fr.) Pouzar

Nemania chestersii (Rogers \& Whalley)

Nemania serpens (Pers.: Fr.) Gray

Neobulgaria pura (Fr.) Petrak

Oligoporus alni (Niemelä \& Vampola) Piątek

Ossicaulis lignatilis (Pers.: Fr.) Redhead \& Ginns

Oudemansiella mucida (Schrad.: Fr.) Höhn.

Panellus serotinus (Pers.: Fr.) Kuhn.

Panellus stipticus (Bull.: Fr.) P.Karst.

Peniophora cinerea (Pers.: Fr.) Cooke

Peniophora incarnata (Pers.: Fr.) P.Karst.

Peziza micropus Pers.: Fr.

Phallus impudicus L.: Pers.

Phlebia livida (Pers.: Fr.) Bres.

Phlebia radiata Fr.: Fr.

Phlebia rufa (Pers.: Fr.) M.P.Christ.

Phlebia tremellosa (Schrad.: Fr.) Burds. \& Nakas.

Phleogena faginea (Fr.: Fr.) Link

Pholiota adiposa (Batsch) P. Kumm.
Cord

Cord

Unknown/different

Cord

Trunk rotters

Unknown/different

Cord

Late stage specialist

Late stage specialist

Late stage specialist

Late stage specialist

Late stage specialist

Unknown/different

Late stage specialist

Late stage specialist

Unknown/different

Unknown/different

Late stage specialist

Late stage specialist

Unknown/different

Late stage specialist

Unknown/different

Late stage specialist

Unknown/different

Late stage specialist

Late stage specialist

Late stage specialist

Late stage specialist

Late stage specialist

Late stage specialist

Unknown/different

Unknown/different

Trunk rotters

Unknown/different

Combative invader

Early ruderals

Early ruderals

Early ruderals

Late stage specialist

Cord

Late stage specialist

Combative invader

Combative invader

Unknown/different

Unknown/different

Trunk rotters
57.14

$-29.46$

53.93

59.27

193.05

210.36

118.91

99.07

236.97

277.19

9.43

20.67

201.17

2.43

79.84

107.69

$-134.95$

$-110.86$

84.13

304.37

63.70

123.86

198.97

$-27.16$

197.23

243.72

68.61

$-37.21$

194.98

219.10

383.75

206.26

181.63

305.90

286.46

291.59

535.10

516.66

181.55

135.39

107.14

367.63

327.39

163.56

207.80

358.33
13.12

299.02

429.85

25.22

40.71

243.32

6.10

$-43.79$

209.19

$-86.29$

380.66

320.52

139.05

150.06

118.40

148.66

283.67

$-61.87$

167.53

268.93

407.34

21.44

255.64

$-68.69$

$-4.25$

$-96.91$

288.15

151.37

32.06

19.18

72.71

160.55

495.46

244.10

116.98

339.83

120.55

370.34

258.78

109.05

228.96

144.79

$-9.71$

35.18

49.83

137.18
14.41

82.07

246.89

295.61

234.14

$-86.16$

222.28

71.61

0.92

8.80

182.41

191.40

266.11

179.60

228.18

102.08

362.96

$-17.90$

201.66

253.41

192.54

2.14

$-92.38$

138.33

$-89.01$

146.37

191.47

89.38

362.06

313.40

90.41

329.13

108.64

109.88

$-5.69$

21.47

172.10

132.61

125.21

299.33

308.50

67.95

219.76

120.42

112.24

$-4.02$ 
Pholiota lenta (Pers.: Fr.) Singer

Pholiota squarrosa (Weigel: Fr.) P.Kumm.

Pholiota squarrosoides (Peck) Sacc.

Pholiotina brunnea (J.E. Lange \& Kühner ex Watling) Singer

Phyllotopsis nidulans (Pers.: Fr.) Singer

Physisporinus vitreus (Pers.) P. Karst.

Pleurotus dryinus (Pers.: Fr.) P.Kumm.

Pleurotus ostreatus (Jacq.: Fr.) P.Kumm.

Pleurotus pulmonarius (Fr.) Quél.

Plicaturopsis crispa (Pers.: Fr.) Reid

Pluteus cervinus (Batsch) Singer

Pluteus chrysophaeus (Schaeff.) Quél.

Pluteus cyanopus Quél.

Pluteus hispidulus (Fr.: Fr.) Gillet

Pluteus insidiosus Vellinga \& Schreurs

Pluteus leoninus (Schaeff.: Fr.) P.Kumm.

Pluteus luctuosus Boud.

Pluteus nanus (Pers.: Fr.) P.Kumm.

Pluteus phlebophorus (Dittm.: Fr.) P.Kumm.

Pluteus plautus (Weinm.) Gillet

Pluteus podospileus Sacc. \& Cub.

Pluteus romellii (Britz.) Sacc.

Pluteus salicinus (Pers.: Fr.) P.Kumm.

Pluteus thomsonii (Berk. \& Br.) Dennis

Pluteus umbrosus (Fr.) P.Kumm.

Polyporus badius (Pers.) Schw.

Polyporus brumalis (Pers.) Fr.: Fr.

Polyporus ciliatus Fr.: Fr.

Polyporus squamosus (Huds.: Fr.) Fr.

Polyporus tuberaster (Pers.: Fr.) Fr.

Polyporus varius (Pers.) Fr.: Fr.

Postia stiptica (Pers.: Fr.) Jülich

Postia tephroleuca (Fr.: Fr.) Jülich

Psathyrella candolleana (Fr.: Fr.) Maire

Psathyrella cernua (Vahl.: Fr.) Hirsch

Psathyrella cotonea (Quél.) Konr. \& Maubl.

Psathyrella multicystidiata Kits van Wav

Psathyrella obtusata (Pers.: Fr.) A.H.Smith

Psathyrella piluliformis (Bull.: Fr.) P.D.Orton

Psathyrella rostellata Örstadius

Psathyrella scobinacea (Fr.) Sing.

Pseudoclitocybe cyathiformis (Bull.: Fr.) Singer

Psilocybe horizontalis (Bul) Vellinga \& Noordel.

Pycnoporus cinnabarinus (Jacq.: Fr.) P.Karst.

Ramaria stricta (Pers.: Fr.) Quél.

Resupinatus applicatus (Batsch: Fr.) Gray

\begin{tabular}{|c|c|c|c|}
\hline Late stage specialist & 293.30 & 102.24 & -89.16 \\
\hline Trunk rotters & 11.21 & 319.97 & -170.90 \\
\hline Trunk rotters & 170.98 & 360.99 & -20.37 \\
\hline Late stage specialist & -61.02 & -59.93 & -77.47 \\
\hline Unknown/different & 317.85 & 337.24 & -63.95 \\
\hline Unknown/different & 43.99 & -37.24 & 21.23 \\
\hline Trunk rotters & 277.74 & -36.38 & 382.53 \\
\hline Trunk rotters & 406.43 & 57.22 & 73.70 \\
\hline Trunk rotters & 374.33 & 329.94 & 42.00 \\
\hline Early ruderals & 517.57 & 249.45 & 113.84 \\
\hline Late stage specialist & 52.24 & 110.02 & 173.37 \\
\hline Late stage specialist & 107.05 & 319.51 & -111.04 \\
\hline Late stage specialist & 71.83 & 445.06 & 135.67 \\
\hline Late stage specialist & 30.19 & -32.30 & -170.01 \\
\hline Late stage specialist & -11.89 & -62.33 & -155.57 \\
\hline Late stage specialist & -38.56 & -113.71 & -168.82 \\
\hline Late stage specialist & -111.13 & 181.26 & -33.80 \\
\hline Late stage specialist & 4.80 & 298.29 & -49.31 \\
\hline Late stage specialist & -22.74 & 149.19 & -62.20 \\
\hline Late stage specialist & 114.53 & 41.87 & -30.41 \\
\hline Late stage specialist & 0.05 & 17.47 & -90.51 \\
\hline Late stage specialist & 42.17 & 318.21 & 265.78 \\
\hline Late stage specialist & -27.81 & 164.40 & 318.99 \\
\hline Late stage specialist & -10.47 & 241.93 & 58.78 \\
\hline Late stage specialist & -22.41 & 136.83 & 79.11 \\
\hline Late stage specialist & 153.53 & -0.69 & 97.14 \\
\hline Combative invader & 332.71 & 181.48 & 6.13 \\
\hline Combative invader & 338.82 & 225.97 & -81.05 \\
\hline Trunk rotters & 219.22 & 373.18 & -31.73 \\
\hline Unknown/different & 261.90 & 237.95 & 37.06 \\
\hline Combative invader & 207.34 & 223.08 & 110.92 \\
\hline Late stage specialist & 210.91 & -131.52 & 26.78 \\
\hline Late stage specialist & 230.58 & 37.18 & 321.77 \\
\hline Unknown/different & 176.36 & 471.12 & -31.91 \\
\hline Trunk rotters & 345.16 & 140.83 & -25.31 \\
\hline Unknown/different & 209.98 & -62.41 & -29.78 \\
\hline Unknown/different & 55.94 & -202.14 & 225.04 \\
\hline Late stage specialist & 31.34 & 246.58 & 394.39 \\
\hline Late stage specialist & 70.70 & -8.09 & 59.10 \\
\hline Late stage specialist & -159.09 & 10.29 & 56.83 \\
\hline Late stage specialist & 40.05 & -108.71 & -217.34 \\
\hline Late stage specialist & 156.08 & 206.31 & 44.85 \\
\hline Early ruderals & 567.42 & -21.61 & 70.29 \\
\hline Early ruderals & 407.74 & 81.33 & 128.43 \\
\hline Cord & -54.79 & 46.39 & 323.70 \\
\hline Unknown/different & 267.00 & 290.65 & -0.63 \\
\hline
\end{tabular}


Schizophyllum commune Fr.: Fr.

Schizopora flavipora (Berk. \& M.A. Curtis ex Cooke) Ryvarden Schizopora paradoxa (Schrad.) Donk

Sidera vulgaris (Fr.) Miettinen

Simocybe centunculus (Fr.: Fr.) P.Karst.

Simocybe rubi (Berk.) Singer

Simocybe sumptuosa (P.D.Orton) Singer

Skeletocutis nivea (Jungh.) Keller

Spongipellis delectans (Peck) Murrill

Spongipellis pachyodon (Pers.) Kotlaba \& Pouzar

Steccherinum fimbriatum (Pers.: Fr.) J.Erikss.

Steccherinum nitidum (Pers.: Fr.) Vesterh.

Steccherinum ochraceum (Pers.: Fr..) Gray

Stereum hirsutum (Willd.) Pers.

Stereum rugosum (Pers.: Fr.) Fr.

Stereum subtomentosum Pouz.

Trametes gibbosa (Pers.: Fr.) Fr.

Trametes hirsuta (Wulfen: Fr.) Pilat

Trametes versicolor (L.: Fr.) Quel.

Trametopsis cervina (Schweinitz) Tomsovský

Tremella foliacea Pers.

Tremella mesenterica Retz: Fr.

Trichaptum abietinum (Pers.: Fr.) Ryvarden

Trichaptum pergamenum (Fr.) G. Cunn.

Trichoderma viride Pers (Hypocrea rufa (Pers.) Fr.) s.lato

Tubaria conspersa (Pers.: Fr.) Fayod

Tyromyces chioneus (Fr.: Fr.) P.Karst.

Xanthoporia nodulosa (Fr.) Tura, Zmitr., Wasser, Raats \& Nevo

Xerula radicata (Relhan: Fr.) Dörfelt

Xylaria hypoxylon (L.: Fr.) Grev.

Xylaria longipes Nitschke

Xylaria polymorpha (Pers.: Fr.) Grev.

\begin{tabular}{|c|c|c|c|}
\hline Early ruderals & 497.80 & 302.69 & 89.19 \\
\hline Unknown/different & 301.42 & -61.97 & 229.59 \\
\hline Early ruderals & 274.32 & 203.56 & 297.12 \\
\hline Late stage specialist & 28.09 & -9.76 & 354.78 \\
\hline Late stage specialist & 152.21 & 328.62 & -19.72 \\
\hline Late stage specialist & 54.61 & -75.24 & -142.27 \\
\hline Late stage specialist & 233.17 & -67.34 & 193.13 \\
\hline Unknown/different & 268.17 & -28.47 & 314.18 \\
\hline Trunk rotters & 165.73 & 451.46 & 248.43 \\
\hline Trunk rotters & 311.61 & 392.02 & 75.49 \\
\hline Cord & -108.13 & 62.35 & 420.31 \\
\hline Late stage specialist & -77.75 & 313.60 & 174.26 \\
\hline Combative invader & 230.31 & 287.71 & 229.33 \\
\hline Combative invader & 302.20 & 247.40 & 134.92 \\
\hline Combative invader & 218.45 & 52.10 & 229.47 \\
\hline Combative invader & 232.20 & -10.54 & 287.00 \\
\hline Combative invader & 300.76 & 117.76 & 106.45 \\
\hline Early ruderals & 371.59 & 294.62 & 31.15 \\
\hline Combative invader & 280.41 & 102.36 & 34.55 \\
\hline Trunk rotters & 275.89 & 483.10 & -33.06 \\
\hline Unknown/different & 357.66 & 51.98 & -28.00 \\
\hline Unknown/different & 428.65 & 229.23 & 31.25 \\
\hline Unknown/different & 477.13 & -64.25 & 263.15 \\
\hline Unknown/different & 390.12 & 301.83 & -110.20 \\
\hline Unknown/different & 289.21 & 261.65 & 219.33 \\
\hline Late stage specialist & 227.43 & -110.84 & -88.47 \\
\hline Late stage specialist & 274.63 & 130.98 & 291.36 \\
\hline Unknown/different & 421.25 & 296.54 & 154.63 \\
\hline Unknown/different & 72.43 & 327.60 & 131.71 \\
\hline Unknown/different & 203.36 & 116.80 & 170.67 \\
\hline Unknown/different & -72.72 & 280.77 & -89.70 \\
\hline Trunk rotters & 114.16 & 188.06 & 7.04 \\
\hline
\end{tabular}




\section{Bryophytes}

\begin{tabular}{|c|c|c|c|c|}
\hline Species & Guild & DCA 1 & DCA 2 & DCA 3 \\
\hline Amblystegium serpens (Hedw.) Br. Eur. & Opportunistic & 39.22 & 98.53 & 71.21 \\
\hline Amblystegium varium (Hedw.) Lindb. & Opportunistic & 212.81 & 336.15 & -87.39 \\
\hline Anomodon attenuatus (Hedw.) Hüb. & Epiphytic & 6.68 & 91.74 & -21.01 \\
\hline Anomodon viticulosus (Hedw.) Hook. \& Tayl. & Epiphytic & 44.48 & 273.50 & -13.14 \\
\hline Antitrichia curtipendula (Hedw.) Brid. & Epiphytic & 237.66 & 421.00 & 169.47 \\
\hline Aulacomnium androgynum (Hedw.) Schwaegr. & Epixylic & 409.18 & -54.33 & -7.89 \\
\hline Blepharostoma trichophyllum (L.) Dum. & Epixylic & -84.13 & 72.74 & 374.06 \\
\hline Brachytheciastrum velutinum (Hedw.) Ignatov \& Huttunen & Opportunistic & 14.39 & 134.16 & 101.64 \\
\hline Brachythecium rutabulum (Hedw.) B., S. \& G. & Opportunistic & 232.31 & 115.20 & 182.15 \\
\hline Brachythecium salebrosum (Web. \& Mohr.) B., S. \& G. & Opportunistic & 176.86 & -8.77 & 126.94 \\
\hline Bryum moravicum Podp. & Opportunistic & 121.46 & 106.50 & 91.84 \\
\hline Calliergonella cuspidata (Hedw.) Loeske & Terricolous & 339.46 & -58.11 & 389.05 \\
\hline Calypogeia azurea Stotler et Crotz & Opportunistic & -74.56 & 56.68 & 524.74 \\
\hline Calypogeia suecica (H. Am et J. Press.) K. Müll. & Epixylic & -72.15 & 52.36 & 435.84 \\
\hline Campylopus flexuosus (Hedw.) Brid. & Opportunistic & 474.84 & 257.25 & 274.12 \\
\hline Campylopus introflexus (Hedw.) Brid. & Opportunistic & 439.91 & 56.80 & 170.84 \\
\hline Campylopus pyriformis (K. F. Schultz) Brid. & Opportunistic & 463.65 & 59.13 & -86.52 \\
\hline Cephalozia bicuspidata (L.) Dum. & Opportunistic & 187.15 & -109.78 & 364.83 \\
\hline Cephalozia catenulata (Hüb.) Lindb. & Epixylic & -96.52 & 39.85 & 416.70 \\
\hline Cephaloziella rubella (Nees) Warnst. & Epixylic & -76.53 & 95.11 & 380.70 \\
\hline Ceratodon purpureus (Hedw.) Brid. & Opportunistic & 235.36 & 88.10 & -58.17 \\
\hline Chiloscyphus polyanthos (L.) Corda & Epixylic & -77.46 & 3.84 & 409.64 \\
\hline Ctenidium molluscum (Hedw.) Mitt. & Epilithic & -61.61 & 162.42 & 286.26 \\
\hline Dicranella heteromalla (Hedw.) Schimp. & Epiphytic & 326.14 & 425.28 & 360.24 \\
\hline Dicranoweisia cirriata (Hedw.) Lindb. Ex Milde & Terricolous & 391.87 & 174.19 & -30.40 \\
\hline Dicranum montanum Hedw. & Epiphytic & 364.78 & 223.08 & 65.76 \\
\hline Dicranum scoparium Hedw. & Opportunistic & 292.73 & 278.87 & 241.71 \\
\hline Dicranum tauricum Sap. & Epiphytic & 384.96 & -88.68 & -25.90 \\
\hline Dicranum viride (Sull. and Lesq.) Lindb. & Epiphytic & -48.08 & 224.32 & 157.67 \\
\hline Encalypta streptocarpa Hedw. & Epilithic & -11.61 & 224.61 & 40.24 \\
\hline Eurhynchium angustirete (Broth.) T. Kop. & Terricolous & -79.21 & 129.94 & 305.42 \\
\hline Eurhynhium striatum (Hedw.) Schimp. & Terricolous & 323.30 & -48.11 & 296.84 \\
\hline Fissidens dubius P. Beauv & Epilithic & -71.29 & 142.49 & 320.82 \\
\hline Frullania dilatata (L.) Dum. & Epiphytic & -0.78 & 286.57 & 5.97 \\
\hline Frullania tamarisci (L.) Dum. & Epiphytic & 252.46 & 414.24 & 194.19 \\
\hline Grimmia hartmanii Schimp. & Epilithic & -12.61 & 244.23 & -62.75 \\
\hline Herzogiella seligeri (Brid.) Iwats. & Epixylic & 161.12 & -22.47 & 250.96 \\
\hline Homalothecium philippeanum (Spruce.) B., S. \& G. & Epilithic & -41.14 & 166.22 & 12.93 \\
\hline Homalothecium sericeum (Hedw.) B., S. \& G. & Epiphytic & 82.11 & 298.94 & 125.08 \\
\hline Hylocomium splendens (Hedw.) Br. Eu. & Terricolous & 328.53 & 417.36 & 428.70 \\
\hline Hypnum cupressiforme Hedw. & Opportunistic & 209.00 & 173.19 & 157.40 \\
\hline Hypnum jutlandicum Holmen \& Warncke & Opportunistic & 476.38 & 266.90 & 155.42 \\
\hline Isothecium alopecuroides (Dubois) Isov. & Epiphytic & 35.44 & 259.70 & 192.41 \\
\hline Isothecium myosuroides Brid. & Epiphytic & 303.58 & 336.57 & 248.43 \\
\hline Jungermannia leiantha Grolle & Epixylic & -76.28 & 36.86 & 407.49 \\
\hline Lejeunea cavifolia (Ehrh.) Lindb. & Epiphytic & -65.16 & 240.02 & 5.11 \\
\hline
\end{tabular}


Lepidozia reptans (L.) Dum.

Epixylic

Leucobryum glaucum (Hedw.) Angstr.

Epixylic

Leucodon sciuroides (Hedw.) Schwaegr.

Epiphytic

Lophocolea bidentata (L.) Dum.

Terricolous

Lophocolea heterophylla (Schrad.) Dum.

Epixylic

Lophocolea minor Nees

Epixylic

Metzgeria conjugata Lindb.

Epiphytic

Metzgeria furcata (L.) Dum.

Epiphytic

Mnium hornum Hedw.

Mnium marginatum (Dicks) P. Beauv.

Terricolous

Epixylic

Mnium stellare Hedw.

Epixylic

Neckera besseri (Lobarz.) Jur.

Epiphytic

Neckera complanata (Hedw.) Hüb.

Epiphytic

Neckera crispa Hedw.

Neckera pumila Hedw.

Nowellia curvifolia (Dicks.) Mitt. in Godman

Orthotrichum affine Brid.

Orthotrichum diaphanum Brid.

Orthotrichum Iyellii Hook. \& Tayl.

Orthotrichum stramineum Hornsch. ex Brid.

Ortotrichum speciosum Nees

Oxyrrhynchium hians (Hedw.) Loeske

Paraleucobryum longifolium (Hedw.) Loeske

Plagiochila porelloides (Torrey ex Nees) Lindenb.

Plagiomnium affine (Bland.) T. Kop.

Plagiomnium cuspidatum (Hedw.) Kop.

Plagiomnium ellipticum (Brid.) Kop.

Plagiomnium undulatum (Hedw.) Kop.

Plagiothecium cavifolium (Brid.) Iwats.

Plagiothecium denticulatum (Hedw.) Br. Eur.

Plagiothecium laetum $\mathrm{Br}$. Eur.

Plagiothecium nemorale (Mitt.) Jaeg.

Plagiothecium undulatum (Hedw.) Br. Eur.

Plasteurhynchium striatulum (Spruce) M. Fleish.

Platygyrium repens (Brid.) B., S. \& G.

Pleurozium schreberi (Brid.) Mitt.

Pohlia nutans (Hedw.) Lindb.

Polytrichastrum formosum (Hedw.) G.L.Sm.

Polytrichastrum longisetum (Sw. ex Brid.) G.L.Sm.

Porella platyphylla (L.) Pfeiff.

Pseudoleskeella nervosa (Brid.) Nyh.

Pseudoscleropodium purum (Hedw.) Fleisch.

Pterigynandrum filiforme Hedw.

Ptilidium pulcherrimum (G. Web.) Vainio

Ptilium crista-castrensis (Hedw.) De Not.

Pylaisia polyantha (Hedw.) Schimp.

Radula complanata (L.) Dum.

Rhizomnium punctatum (Hedw.) Kop.

Rhynchostegium confertum (Dicks.) B., S. \& G.

Epiphytic

Epiphytic

Epixylic

Epiphytic

Epiphytic

Epiphytic

Epiphytic

Epiphytic

Terricolous

Epiphytic

Opportunistic

$$
473.53
$$

$-45.24$

77.03

391.79

254.10

278.58

$-39.24$

265.57

$-18.12$

320.18

181.19

180.86

$-161.22$

22.92

357.59

$-68.74$

107.66

6.40

89.19

248.02

81.72

73.40

313.47

222.30

360.01

$-46.34$

177.72

152.67

48.72

343.65

$-59.83$

$-149.72$

$-42.97$

5.30

$-67.15$

391.93

Terricolous

Opportunistic

Opportunistic

Terricolous

Terricolous

Epixylic

Epiphytic

Epixylic

Terricolous

Opportunistic

Epiphytic

Terricolous

Terricolous

Terricolous

Opportunistic

Epiphytic

Epiphytic

Terricolous

Epiphytic

Opportunistic

Terricolous

Epiphytic

Epiphytic

Epixylic

Epiphytic

$107.47 \quad 323.66$

281.50

262.03

$-151.51$

149.84

277.69

408.62

136.20

220.50

304.44

315.60

321.25

361.92

334.73

486.80

188.69

13.65

456.76

$-13.39$

264.53

2.02

133.64

20.93

356.82

45.47

$-77.35$

544.22

$-18.78$

67.91

309.13

23.60 
Rhynchostegium murale (Hedw.) B., S. \& G.

Rhytidiadelphus loreus (Hedw.) Warnst.

Rhytidiadelphus squarrosus (Hedw.) Warnst.

Epilithic

Terricolous

$-43.45$

236.44

12.77

Rhytidiadelphus triquetrus (Hedw.) Warnst.

Terricolous

Terricolous

Riccardia latifrons (Lindb.) Lindb.

Epixylic

Epixylic

Epixylic

Riccardia palmata (Hedw.) Carruth.

Opportunistic

Opportunistic

Opportunistic

Epilithic

284.75

392.12

379.76

Sanionia uncinata (Hedw.) Loeske

Sciuro-hypnum populeum (Hedw.) Ignatov \& Huttunen

333.86

255.00

360.61

Sciuro-hypnum reflexum (Starke) Ignatov \& Huttunen

Epixylic

Tetraphis pellucida Hedw.

Thamnobryum alopecurum (Hedw.) Gang.

Thuidium tamariscinum (Hedw.) B., S. \& G.

Epiphytic

Tortella tortuosa (Hedw.) Limpr.

Tortula subulata Hedw.

Ulota crispa (Hedw.) Brid.

Zygodon conoideus (Dicks.) Hook. \& Tayl.

Terricolous

$-83.99$

161.79

235.56

$-23.79$

12.69

373.35

$-94.64 \quad 45.25$

384.41

$\begin{array}{lll}-71.94 & 139.11 & 314.67\end{array}$

$\begin{array}{lll}7.72 & 174.77 & 269.48\end{array}$

$\begin{array}{lll}21.05 & 198.12 & 23.47\end{array}$

$\begin{array}{lll}305.54 & 467.87 & 322.94\end{array}$

$-7.81 \quad 144.16$

$-57.15$

$\begin{array}{lll}241.71 & 143.94 & 379.60\end{array}$

$-84.82$

114.93

331.82

Opportunistic

27.17

99.93

341.71

Epilithic

$-60.53$

202.74

204.02

Epiphytic

$-21.51$

81.50

$-74.73$

Epiphytic

105.85

268.56

$-45.14$

Zygodon rupestris Schimp. Ex Lor.

Epiphytic

399.61

363.99

$-30.36$

69.71

307.26

74.70


Appendix S3: Kendall rank correlation matrix for all included variables. Correlations with Kendall's tau exceeding $+0.5 /-0.5$ are highlighted in bold.

3

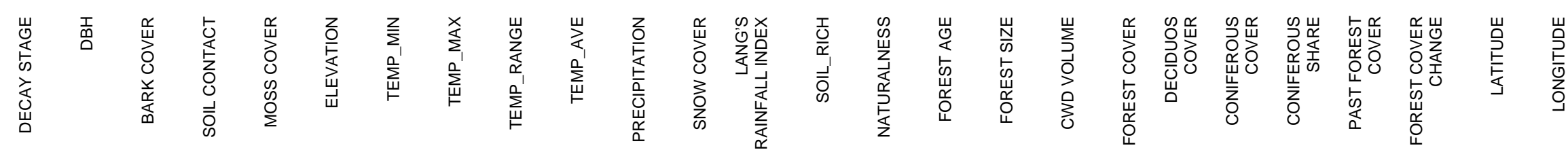

DECAY STAGE

$$
\text { DBH }
$$

BARK COVER

SOIL CONTACT

MOSS COVER

ELEVATION

TEMP_MIN

TEMP_MAX

TEMP_RANGE

TEMP_AVE

PRECIPITATION

SNOW COVER

LANG'S RAINFALL

INDEX

SOIL_RICH

NATURALNESS

TREE AGE

FOREST SIZE

CWD VOLUME

FOREST COVER

DECIDUOS COVER

CONIFEROUS COVER

CONIFEROUS SHARE
PAST FOREST

FOVER

CHANGE

LATITUDE

LONGITUDE

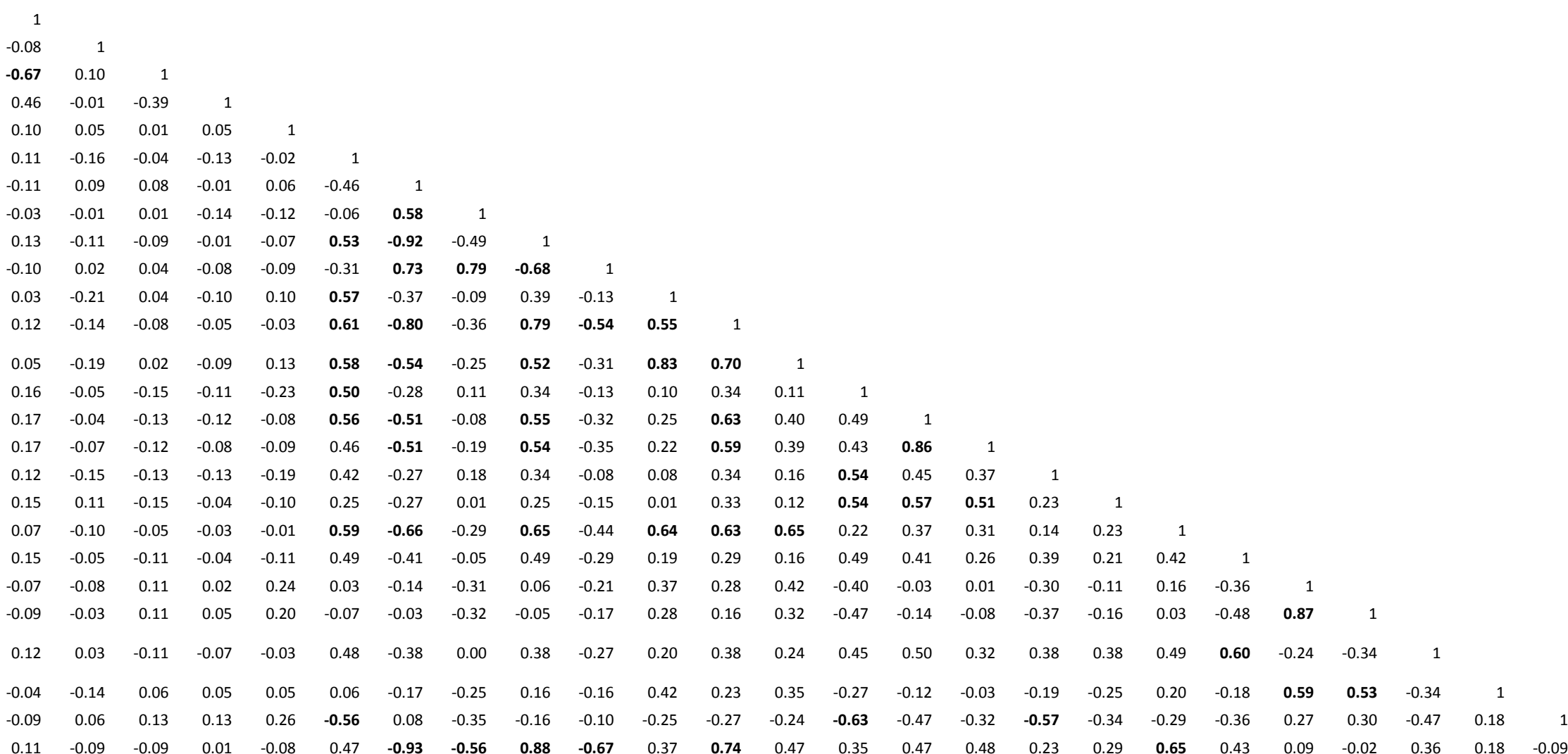

